\title{
Endogeous sulfur dioxide protects against oleic acid-induced acute lung injury in association with inhibition of oxidative stress in rats
}

\author{
Siyao Chen ${ }^{1,5}$, Saijun Zheng ${ }^{2,5}$, Zhiwei Liu' ${ }^{2}$, Chaoshu Tang ${ }^{3,4}$, Bin Zhao ${ }^{2}$, Junbao Du ${ }^{1,4}$ and Hongfang Jin ${ }^{1}$
}

The role of endogenous sulfur dioxide $\left(\mathrm{SO}_{2}\right)$, an efficient gasotransmitter maintaining homeostasis, in the development of acute lung injury (ALI) remains unidentified. We aimed to investigate the role of endogenous $\mathrm{SO}_{2}$ in the pathogenesis of ALI. An oleic acid (OA)-induced ALI rat model was established. Endogenous $\mathrm{SO}_{2}$ levels, lung injury, oxidative stress markers and apoptosis were examined. OA-induced ALI rats showed a markedly downregulated endogenous $\mathrm{SO}_{2}$ /aspartate aminotransferase 1 (AAT1)/AAT2 pathway and severe lung injury. Chemical colorimetry assays demonstrated upregulated reactive oxygen species generation and downregulated antioxidant capacity in OA-induced ALI rats. However, $\mathrm{SO}_{2}$ increased endogenous $\mathrm{SO}_{2}$ levels, protected against oxidative stress and alleviated ALI. Moreover, compared with OA-treated cells, in human alveolar epithelial cells $\mathrm{SO}_{2}$ downregulated $\mathrm{O}_{2}{ }^{-}$and $\mathrm{OH}^{-}$generation. In contrast, L-aspartic acid- $\beta$-hydroxamate (HDX, Sigma-Aldrich Corporation), an inhibitor of endogenous $\mathrm{SO}_{2}$ generating enzyme, promoted free radical generation, upregulated poly (ADP-ribose) polymerase expression, activated caspase-3, as well as promoted cell apoptosis. Importantly, apoptosis could be inhibited by the free radical scavengers glutathione (GSH) and N-acetyl-L-cysteine (NAC). The results suggest that $\mathrm{SO}_{2} / \mathrm{AAT} 1 / \mathrm{AAT} 2$ pathway might protect against the development of OA-induced ALI by inhibiting oxidative stress.

Laboratory Investigation (2015) 95, 142-156; doi:10.1038/labinvest.2014.147; published online 12 January 2015

Acute lung injury (ALI) and its more severe form, acute respiratory distress syndrome (ARDS), both with high mortality rates and significant shortage of reliable therapeutic intervention, may result from direct and indirect insults to the lung. ${ }^{1,2}$ Since the first description of ALI/ARDS, in 1967, numerous studies have been conducted to better understand the pathogenesis. ${ }^{3,4}$ Exposure to hazardous factors such as acid, lipopolysaccharide, hyperoxia, or overinflation generates excessive levels of reactive oxygen species (ROS) and recruitment of considerable amounts of neutrophils in lung tissue, thus resulting in proinflammatory processes and eventually cellular, and tissue dysfunction, which contributes to increased vascular permeability, leukocyte infiltration, plasma exudation and impaired arterial oxygenation. ${ }^{5,6}$

The canonical role of oxidative stress in the development of ALI has been established. ${ }^{7-9}$ Oxidative stress arises with an imbalance between production of free radicals and reactive metabolites such as hydrogen peroxide $\left(\mathrm{H}_{2} \mathrm{O}_{2}\right)$, superoxide anion $\left(\mathrm{O}_{2}{ }^{-}\right)$, and hydroxyl radical $\left(\mathrm{OH}^{-}\right)$, the so-called ROS, and their elimination by protective mechanisms, antioxidants such as superoxide dismutase (SOD).${ }^{10-12}$ Most ROS is generated in cells by the mitochondrial respiratory chain, which under hypoxic conditions produces nitric oxide (NO), thus resulting in generation of reactive nitrogen species (RNS). ${ }^{13}$ RNS can further generate other reactive species by inducing excessive lipid peroxidation. This imbalance leads to damage of important biomolecules and cells, with potential impact on the whole organism. However, how oxidative stress regulates ALI remains elusive.

Recent reports regarding the emerging regulatory role of endogenous sulfur dioxide $\left(\mathrm{SO}_{2}\right)$ in the cardiovascular system have attracted attention. Previously considered an

\footnotetext{
${ }^{1}$ Department of Pediatrics, Peking University First Hospital, Beijing, China; ${ }^{2}$ Department of Emergency, Beijing Jishuitan Hospital, Beijing, China; ${ }^{3}$ Department of Physiology and Pathophysiology, Peking University Health Science Center, Beijing, China and ${ }^{4}$ Department of Gasotransmitters and Cardiovascular Diseases, Key Laboratory of Molecular Cardiology, Ministry of Education, Beijing, China

Correspondence: Professor B Zhao, MD, Department of Emergency, Beijing Jishuitan Hospital, No. 31, Xin'Jiekou East Street, Beijing 100035, China or Professor J Du, MD or Professor H Jin, PhD, Department of Pediatrics, Peking University First Hospital, No. 1, Xi'anmen Street, Beijing 100034, China.

E-mail: zhaobin60@yahoo.com.cn or junbaodu1@126.com or jinhongfang51@126.com

${ }^{5}$ These two authors contributed equally to this work.

Received 22 April 2014; revised 4 October 2014; accepted 21 October 2014
} 
industrial pollutant, $\mathrm{SO}_{2}$ is now detected in mammals and generated from a sulfur-containing amino acid, L-cysteine. L-cysteine is first oxidized by cysteine dioxygenase to L-cysteinesulfinate, which could be converted by aspartate aminotransferase (AAT) to b-sulfinylpyruvate, and then decomposes to pyruvate and $\mathrm{SO}_{2} \cdot{ }^{14,15} \mathrm{SO}_{2}$ is further metabolized to form sulfite and oxidized by sulfite oxidase to sulfate, which is eventually excreted in urine. In neutral $\mathrm{pH}$, $\mathrm{SO}_{2}$ dissociates to sulfite derivatives $\left(\mathrm{NaHSO}_{3} / \mathrm{Na}_{2} \mathrm{SO}_{3}, 1: 3\right.$ $\mathrm{M} / \mathrm{M}$ ), and with its properties of low molecular weight, continuous release, quick dispersal, and absorbance, $\mathrm{SO}_{2}$ might be an important mediator in the cardiovascular system, contributing to the maintenance of homeostasis in vivo. ${ }^{16}$ Although the biological effects of endogenous $\mathrm{SO}_{2}$ have yet to be discovered, $\mathrm{SO}_{2}$ may be endogenously produced by pulmonary vessels to regulate vascular activities and may be involved in the inflammatory response in pulmonary vascular structural remodeling. ${ }^{17}$ In addition, endogenous $\mathrm{SO}_{2}$ could impact myocardial antioxidant capacity in rats. ${ }^{18}$

On the basis of these discoveries, we designed in vivo and in vitro experiments to investigate whether the endogenous $\mathrm{SO}_{2}$ /AAT1/AAT2 pathway is involved in the development of oleic acid (OA)-induced ALI in rats and its possible mechanisms.

\section{MATERIALS AND METHODS Animals}

The experiments conform to the Institutional Authority for Laboratory Animal Care of Peking University, which complies with the Guide for the Care and Use of Laboratory Animals published by the US National Institutes of Health.

We randomly divided 100 male Wistar rats (250-300 g) into four groups for treatment ( $n=18$ each): control, OA, OA+ $\mathrm{SO}_{2}$, and control $+\mathrm{SO}_{2}$. The OA-induced ALI rat model was established. ${ }^{19,20}$ Control rats were treated with physiological saline at a dosage of $0.1 \mathrm{ml} / \mathrm{kg}$ body weight, by intravenous injection; $\mathrm{OA}$ group was given $\mathrm{OA}$ at a dosage of $0.1 \mathrm{ml} / \mathrm{kg}$ body weight, by intravenous injection for $2 \mathrm{~h}$ and $6 \mathrm{~h}$, respectively. In $\mathrm{OA}+\mathrm{SO}_{2}$ group, $\mathrm{SO}_{2}$ derivatives, sodium sulfite/sodium bisulfite $\left(\mathrm{Na}_{2} \mathrm{SO}_{3} / \mathrm{NaHSO}_{3}\right)$ at a dosage of $0.54 \mathrm{mmol} / \mathrm{kg}$ body weight, were freshly dissolved in deionized water and applied by intraperitoneal injection $30 \mathrm{~min}$ before $\mathrm{OA}$ treatment. Rats in control $+\mathrm{SO}_{2}$ group were first injected with $\mathrm{Na}_{2} \mathrm{SO}_{3} / \mathrm{NaHSO}_{3}(0.54 \mathrm{mmol} / \mathrm{kg}$, intraperitoneally), and $30 \mathrm{~min}$ later administered with physiological saline $(0.1 \mathrm{ml} / \mathrm{kg}$, intravenous injection). $\mathrm{OA}$ and $\mathrm{SO}_{2}$ derivatives were purchased from Sigma-Aldrich Corporation (St Louis, MO, USA), physiological saline was purchased from Peking University First Hospital (Beijing, China), and other chemicals were purchased from Beijing Chemical Reagents (Beijing, China). All rats were housed under identical conditions.

\section{Assessment of ALI}

We examined rat lung gross morphology, hematoxylin and eosin (H\&E) staining of representative rat lung tissue sections, ratio of wet to dry weight (W/D) of the lung, and partial pressure of oxygen in the arterial blood $\left(\mathrm{PaO}_{2}\right){ }^{21}$ Rat lung tissue was exposed and different groups of rat lung gross morphology pictures were obtained. Representative lung tissue sections from 2 and $6 \mathrm{~h}$ after surgery $(n=7$ animals per group) were fixed in $4 \%$ formaldehyde, and were prepared for H\&E staining following routine methods. Rat lung tissue was first dehydrated by ethanol and made transparent by dimethylbenzene, and then embedded in paraffin. Embedded lung tissue was fixed on microtome and sliced to the thickness of 5-8 $\mu \mathrm{m}$. After being dewaxed by dimethylbenzene, tissue slides were treated with $100 \%$ ethanol, $95 \%$ ethanol, and $75 \%$ ethanol for $10 \mathrm{~min}$, respectively. Slides were soaked in phosphate buffer solution (PBS) for $10 \mathrm{~min}$ before being dyed with hematoxylin for $2 \mathrm{~min}$. Eosin was added on slides for $5 \mathrm{~min}$. Dyed slides were dehydrated by graded ethanol series and made transparent again by dimethylbenzene. Slides were covered with coverslips and dried in a heating block before being observed under a light microscope. Lung wet and dry weight was recorded and W/D was calculated. Blood gas indices including $\mathrm{pH}$, and partial pressure of carbon dioxide $\left(\mathrm{PaCO}_{2}\right)$ and $\mathrm{PaO}_{2}$ were measured.

\section{Measurement of $\mathrm{SO}_{2}$ Production in Tissue}

$\mathrm{SO}_{2}$ content in rat lung tissue was determined by high-performance liquid chromatography (HPLC; Agilent 1100 series, Agilent Technologies, Palo Alto, CA, USA). ${ }^{22}$ In brief, tissue homogenate $(100 \mathrm{ml})$ was mixed with $70 \mathrm{ml}$ of $0.212 \mathrm{mM}$ sodium borohydride in $0.05 \mathrm{M}$ Tris- $\mathrm{HCl}(\mathrm{pH} 8.5)$ and incubated at room temperature for $30 \mathrm{~min}$, which was then mixed with $10 \mathrm{ml}$ of $70 \mathrm{mM}$ monobromobimane in acetonitrile. After incubation for $10 \mathrm{~min}$ at $42{ }^{\circ} \mathrm{C}, 50 \mathrm{ml}$ of $1.5 \mathrm{M}$ perchloric acid was added, followed by vortex mixing. Then, mixtures were centrifuged at $12400 \mathrm{~g}$ for $10 \mathrm{~min}$ and the supernatant was neutralized by $20 \mathrm{ml}$ of $2.0 \mathrm{M}$ Tris, and subsequently mixed and centrifuged again at $12400 \mathrm{~g}$ for $10 \mathrm{~min}$. The neutralized supernatant (about $100 \mathrm{ml}$ ) was transferred and stored at $4{ }^{\circ} \mathrm{C}$ in foil-wrapped tubes, and the supernatant was injected onto a HPLC column. The column $(4.6 \times 150 \mathrm{~mm}$ C18 reverse-phase column, Agilent series 1100; Agilent Technologies, Karlsruhe, Germany) was equilibrated with buffer containing methanol/acetic acid/water = 5.00:0.25:94.75 by volume, $\mathrm{pH}$ 3.4. The samples loaded onto the column were resolved by a gradient of methanol for $0-5 \mathrm{~min}, 3 \%$; $5-13 \mathrm{~min}, 3-35 \%$; $13-30 \mathrm{~min}, 35-62 \%$; 30-31 min, 62-100\%; 31-39 min, $100 \%$; 39-40 min, $100-3 \%$; and $40-45 \mathrm{~min}, 3 \%$ at a flow rate of $1.0 \mathrm{ml} / \mathrm{min}$. Sulfitebimane adduct was detected by excitation at $392 \mathrm{~nm}$ and emission at $479 \mathrm{~nm}$.

\section{Western Blotting Analysis of AAT1 and AAT2 Protein Expression}

Rat lung tissue homogenate and human alveolar epithelial cell lysate were prepared for western blot analysis. ${ }^{23}$ First, lung tissue homogenate was centrifuged at 12000 r.p.m. for 
$20 \mathrm{~min}$ and supernatant was subsequently mixed with $2 \times$ loading buffer. Cells were harvested from six-well plates and dissolved in lysate buffer, which was subsequently mixed with $2 \times$ loading buffer. The composition of ice-cold protein lysate buffer contained $50 \mathrm{mmol} / \mathrm{l}$ Tris- $\mathrm{HCl}$ ( $\mathrm{pH}$ 7.4), $150 \mathrm{mmol} / \mathrm{l} \mathrm{NaCl}, \quad 1 \mathrm{mmol} / \mathrm{l}$ ethylenediamine tetraacetic acid, $1 \%$ Nonidet $\mathrm{P}-40,0.25 \%$ sodium deoxycholate, $1 \mathrm{mmol} / \mathrm{l} \mathrm{PMSF}$, protease, as well as phosphatase inhibitors. The mixture was boiled at $100^{\circ} \mathrm{C}$ for $5 \mathrm{~min}$ and cooled down at room temperature. Protein concentration was detected with a Bradford protein assay kit. Equal amounts of protein $(30-60 \mu \mathrm{g})$ were loaded on $10-12 \%$ SDS-polyacrylamide gels and transferred to nitrocellulose membranes. The primary antibody dilutions were 1:1000 for AAT1 (Cell Signaling Technology, Danvers, MA, USA), 1:5000 for AAT2 (Cell Signaling Technology), and 1:5000 for GAPDH (Kang Cheng, Shanghai, China). Secondary antibodies were used at a dilution of 1:10000. Chemiluminescence was exposed to X-ray film (Kodak Scientific) and blot was scanned and quantified by AlphaEase FC (Alpha Innotech Corporation, USA) software.

\section{Chemical Colorimetry Assay}

The relative concentration or activity of oxidants including $\mathrm{H}_{2} \mathrm{O}_{2}, \mathrm{OH}^{-}$, MDA, myeloperoxidase (MPO), GSH disulfide (GSSG), NO and inducible isoform of NO synthases (iNOS), and antioxidants including total antioxidant capacity (TAC), catalase, SOD, GSH peroxidase (GPx), and GSH in rat lung tissue were determined by detection kits (Nanking Jiancheng Bioengineering Institute, Nanjing, China). Chemical colorimetry assays were performed according to manufacturer's guidelines. Each group of lung tissue homogenate was diluted to the same concentration with distilled water and subsequently subjected to chromogenic reaction according to instructions, and the absorbance values of each tube at specific wavelengths were measured and the relative activity or concentration of various biochemical parameters was calculated according to formulas provided by guidelines.

\section{Western Blotting and Immunohistochemistry Analysis of SOD1 and SOD2}

Rat lung tissue lysate was prepared for western blot analysis of SOD1 and SOD2 as follows. First, lung tissue homogenate was centrifuged at 12000 r.p.m. for $20 \mathrm{~min}$ and supernatant was subsequently mixed with $2 \times$ loading buffer. The mixture was boiled at $100{ }^{\circ} \mathrm{C}$ for $5 \mathrm{~min}$ and cooled down at room temperature. Protein concentration was detected by a Bradford protein assay kit. Equal amounts of protein $(30-60 \mu \mathrm{g})$ were loaded on 10-15\% SDS-polyacrylamide gels and transferred to nitrocellulose membranes. The primary antibody dilutions were 1:1000 for SOD1 and SOD2 (Santa Cruz Biotechnology), and 1:5000 for GAPDH. Secondary antibodies were used at a dilution of 1:8000. Chemiluminescence was exposed to X-ray film and blot scanned and quantified by AlphaEase FC software.
Upper left lobe of the lung tissue slides were prepared for immunohistochemical analysis as follows. The tissue samples were dehydrated and embedded in paraffin following routine methods. Tissue sections with the thickness of $3-5 \mu \mathrm{m}$ were sliced by microtome and were treated following a standard immunohistochemistry protocol. After being dewaxed by dimethylbenzene, sections were rehydrated through graded ethanol series. Hydrated sections were rinsed with PBS before being incubated with $3 \% \mathrm{H}_{2} \mathrm{O}_{2}$ for $10 \mathrm{~min}$ at room temperature in a humid chamber. Slides were rinsed again with PBS and then incubated with goat serum for $30 \mathrm{~min}$ at a temperature of $37{ }^{\circ} \mathrm{C}$. Primary antibody dilution for SOD1 and SOD2 was 1:100 and 1:200, respectively. Slides were incubated with primary antibody overnight at $4{ }^{\circ} \mathrm{C}$, and then rinsed with PBS before secondary antibody was applied. Then, 3,3-diaminobenzidine (DAB) was added to develop color, and the sections were stained with hematoxylin for 30 s. Slides were dehydrated through a graded ethanol series and made transparent in dimethylbenzene. The brown granules in pulmonary epithelial cells under light microscopy were defined as positive signals (magnification: $\times 400$ ). Semi-quantitative optical density analysis was performed by Qwin Image Analysis System (Q550CW, Leica, Germany). ${ }^{24}$

\section{Cell Culture and Treatment}

The A549 cell line was used as a source of human alveolar epithelial cells (obtained from ATCC, CCL185), and cell viability was measured by a modified MTT assay. ${ }^{25}$ A549 human alveolar cells were cultured in an incubator at a temperature of $37^{\circ} \mathrm{C}$, with $5 \% \mathrm{CO}_{2}$. Dulbecco's Modified Eagle's Medium (DMEM) mixed with $10 \%$ fetal bovine serum (FBS), $1 \%$ streptomycin, $1 \%$ penicillin, and $1 \%$ glutamine were used to culture cells. Culture medium was changed every 3 days. Synchronization medium contained no FBS and was incubated with cells for $24 \mathrm{~h}$ before drug administration. Cells were first cultured in 96 well with a final volume of $100 \mu \mathrm{l} /$ well medium, incubated with different concentration of OA (Sigma-Aldrich) and $\mathrm{SO}_{2}$ for $30 \mathrm{~min}$ and $24 \mathrm{~h}$, respectively, and then $10 \mu \mathrm{l}$ of WST-1 (Beyotime Institute of Biotechnology, Suzhou, China) was added to each well, and subsequently incubated for another $2 \mathrm{~h}$ at $37^{\circ} \mathrm{C}$. Immediately after the incubation, the absorbance of sample was measured under a wavelength of $450 \mathrm{~nm}$ by Fluorescence Microplate Reader (FLx800, Biotek, USA). A549 human alveolar epithelial cells were divided into vehicle, $\mathrm{OA}, \mathrm{OA}+\mathrm{SO}_{2}$, HDX, HDX + GSH (Amresco, Solon, OH, USA), and HDX + NAC (Amresco) groups. A549 cells in OA group were treated with $10 \mu \mathrm{M}$ OA for 30 min, whereas A549 cells in $\mathrm{OA}+\mathrm{SO}_{2}$ group were incubated with $50 \mu \mathrm{M} \mathrm{SO}_{2}$ for $30 \mathrm{~min}$ before administration of OA. Then, A549 cells were treated with different concentrations $(50,100,150,200$ and $500 \mu \mathrm{M})$ and at various time points $(0.5,1,1.5$ and $2 \mathrm{~h})$ of $\mathrm{HDX}$, with $\mathrm{SO}_{2}$ levels in supernatant detected by HPLC and AAT activities by commercial kits (Nanjing Jiancheng Bioengineering Institute, Nanjing, China). HDX was given at $150 \mu \mathrm{M}$ for 
$1 \mathrm{~h}$, whereas $5 \mathrm{mM}$ GSH and $1 \mathrm{mM}$ NAC were administered 30 min before HDX treatment.

\section{Detection of $\mathrm{O}_{2}{ }^{-}$Production in A549 cells by Fluorescent Probe}

$\mathrm{O}_{2}{ }^{-}$production in living A549 cells was detected by dihydroethidium (DHE, Beyotime Institute of Biotechnology). A549 human alveolar epithelial cells were cultured in six wells with DMEM containing 10\% FBS. Cells were divided into vehicle-treated group, OA-treated group, $\mathrm{OA}+\mathrm{SO}_{2}$-treated group, HDX-treated group, HDX + GSH-treated group, and HDX + NAC-treated group. Before drug administration, all cells were synchronized in DMEM without FBS for $24 \mathrm{~h}$. In OA-treated group, cells were treated with $10 \mu \mathrm{M}$ OA for $30 \mathrm{~min}$. In $\mathrm{OA}+\mathrm{SO}_{2}$-treated group, cells were incubated with $50 \mu \mathrm{M} \mathrm{SO}_{2}$ donor freshly dissolved in deionized water $30 \mathrm{~min}$ before OA treatment. In HDX-treated group, cells were incubated with $150 \mu \mathrm{M}$ HDX for $1 \mathrm{~h}$. In HDX + GSH-treated group, $5 \mathrm{mM}$ GSH was administered $30 \mathrm{~min}$ before HDX treatment. In HDX + NAC-treated group, $1 \mathrm{mM}$ NAC was administered $30 \mathrm{~min}$ before HDX treatment. After drug administration, cells were incubated with $5 \mu \mathrm{mol} / \mathrm{l}$ of DHE for $30 \mathrm{~min}$ at $37^{\circ} \mathrm{C} .{ }^{26} \mathrm{DHE}$ fluorescence with excitation wavelength at $325 \mathrm{~nm}$ and emission wavelength at $610 \mathrm{~nm}$ (red) was detected by Fluorescence Inversion Microscope System (DMI4000B, Leica, Germany). High-resolution optical image magnified 20 times and 40 times was obtained.

\section{Quantification of $\mathrm{OH}^{-}$Generation in A549 cells by Fluorescence Analysis}

$\mathrm{OH}^{-}$content in living cells was detected by $\mathrm{OH}^{-}$reagent kit (Genmed Scientific, USA). A549 human alveolar cells were cultured in 96 wells with DMEM containing 10\% FBS. Cells were divided into vehicle-treated group, OA-treated group, and $\mathrm{OA}+\mathrm{SO}_{2}$-treated group. Before drug administration, all cells were starved in DMEM without FBS for $24 \mathrm{~h}$. In OA-treated group, cells were treated with $10 \mu \mathrm{M}$ OA for $30 \mathrm{~min}$. In $\mathrm{OA}+\mathrm{SO}_{2}$-treated group, cells were incubated with $50 \mu \mathrm{M} \mathrm{SO}_{2}$ donor freshly dissolved in deionized water $30 \mathrm{~min}$ before OA treatment. Cells were rinsed with Genmed cleaning solution before incubation with Genmed staining solution for $30 \mathrm{~min}$ at a temperature of $37^{\circ} \mathrm{C}$. Then, staining solution was removed and cells were rinsed with cleaning solution, and fluorescence was immediately analyzed by Fluorescence Fluoroskan Ascent Microplate Fluorometer (Thermo Scientific, USA). Hydroxyphenyl fluorescein (2-[6(4'-Hydroxy) phenoxy-3 H-xanthen-3-on-9-yl] benzoic acid, HPF) could freely pass through cell membranes, react with $\mathrm{OH}^{-}$, and produce fluorescein with excitation wavelength at $499 \mathrm{~nm}$ and emission wavelength at $515 \mathrm{~nm}$ (green).

\section{Localization of Poly (ADP-ribose) Polymerase (PARP) Expression in A549 Cells by Immunofluorescence}

A549 human alveolar epithelial cells were seeded on glass and cultured in six wells with DMEM containing 10\% FBS. Cells were divided into vehicle-treated group, HDX-treated group, HDX + GSH-treated group, and HDX + NAC-treated group. Before drug administration, all cells were starved for $24 \mathrm{~h}$. In HDX-treated group, cells were incubated with $150 \mu \mathrm{M}$ HDX for $1 \mathrm{~h}$. In $\mathrm{HDX}+\mathrm{GSH}$-treated group, $5 \mathrm{mM}$ GSH was administered $30 \mathrm{~min}$ before HDX treatment. In HDX + NAC-treated group, $1 \mathrm{mM}$ NAC was administered $30 \mathrm{~min}$ before HDX treatment. After different treatment according to group, alveolar cells were washed twice with PBS before fixation with ice-cold $1 \%$ paraformaldehyde for $20 \mathrm{~min}$. Then, cells were blocked with $1 \%$ bovine serum albumin in PBS containing $0.2 \%$ Triton X-100 for $30 \mathrm{~min}$, and were incubated with anti-PARP antibody (1:100, Cell Signaling Technology) at $4{ }^{\circ} \mathrm{C}$ overnight. Cells were washed with PBS three times and incubated with secondary antibody (antirabbit-FITC conjugated, Molecular Probes) at $37^{\circ} \mathrm{C}$ for $1 \mathrm{~h}$ the next morning. Nuclei were subsequently stained with propidium iodide (PI; Sigma) for $5 \mathrm{~min}$ and rinsed in PBS for three times. Coverslips were mounted onto slides using ProLong anti-fade mounting reagent (Molecular Probes). Immunofluorescence analysis was performed under a confocal laser-scanning microscope (TCS SP5, Leica Microsystems, Germany) by use of an excitation wavelength in the range of 450-500 $\mathrm{nm}$ and emission wavelength in the range of 515$565 \mathrm{~nm}$ (green) for PARP, as well as an excitation wavelength at $535 \mathrm{~nm}$ and emission wavelength at $615 \mathrm{~nm}$ (red) for PI.

\section{Analysis of Cleaved Caspase-3 and Caspase-3 Protein Expression by Western Blotting}

A549 human alveolar epithelial cells were cultured in six wells with DMEM containing 10\% FBS. Cells were divided into vehicle-treated group, HDX-treated group, HDX + GSH-treated group, and HDX + NAC-treated group. In HDX-treated group, cells were incubated with $150 \mu \mathrm{M}$ HDX for $1 \mathrm{~h}$. Before drug administration, all cells were starved for $24 \mathrm{~h}$. In $\mathrm{HDX}+\mathrm{GSH}$-treated group, $5 \mathrm{mM}$ GSH was administered $30 \mathrm{~min}$ before HDX treatment. In HDX + NAC-treated group, $1 \mathrm{mM} \mathrm{NAC}$ was administered $30 \mathrm{~min}$ before HDX treatment. Immediately after treatment, A549 cells were rinsed with PBS, scraped off six wells, and incubated in lysate buffer at $4{ }^{\circ} \mathrm{C}$ for $30 \mathrm{~min}$ before mixed with equal volume of $2 \times$ loading buffer. The mixture was boiled in $100^{\circ} \mathrm{C}$ water and cooled down to room temperature. Protein concentration was detected by a Bradford protein assay kit (M173-KIT, Amresco, America). Equal amounts of protein $(30-60 \mu \mathrm{g})$ were loaded on $10-12 \%$ SDS-polyacrylamide gels and transferred to nitrocellulose membranes. Strips were blocked with $5 \%$ blocking milk for $1 \mathrm{~h}$ at room temperature. The primary antibody dilutions were 1:500 for cleaved caspase-3 (Cell Signaling Technology), 1:1000 for caspase-3 (Cell Signaling Technology) and 1:5000 for GAPDH. Secondary antibody (Cell Signaling Technology) was used at a dilution of 1:10 000. Strips were incubated with primary antibody at $4{ }^{\circ} \mathrm{C}$ overnight and rinsed the following morning in PBS for 40 min before incubating with secondary 
antibody for $1 \mathrm{~h}$ at room temperature. Strips were subsequently washed in PBS three times, each time for $10 \mathrm{~min}$. Chemiluminescence was applied and strips were exposed to X-ray film and blot scanned, and quantified by AlphaEase FC software. Blot was quantified by AlphaEase FC software.

\section{Hoechst Staining of Apoptotic Cell Nucleus and Apoptotic Bodies}

Apoptotic Cell nucleus and Apoptotic Bodies Detection Kit (Applygen Technologies, Beijing, China) based on Hoechst staining were used for determination of cell apoptosis. A549 human alveolar epithelial cells were cultured in 24 wells with DMEM containing 10\% FBS. Cells were divided into vehicletreated group, HDX-treated group, $\mathrm{HDX}+\mathrm{GSH}$-treated group, and HDX + NAC-treated group. Before drug administration, all cells were starved for $24 \mathrm{~h}$. In $\mathrm{HDX}+\mathrm{GSH}-$ treated group, $5 \mathrm{mM}$ GSH was administered $30 \mathrm{~min}$ before HDX treatment. In HDX + NAC-treated group, $1 \mathrm{mM} \mathrm{NAC}$ was administered 30 min before HDX treatment. After drug treatment, slides were washed twice with PBS before fixation with $4 \%$ paraformaldehyde in $\mathrm{PBS}$ for $40 \mathrm{~min}$ at $37^{\circ} \mathrm{C}$. Adherent cells in each well were incubated with $5 \mu$ l of $100 \times$ staining solution mixed with $0.5 \mathrm{ml}$ of PBS for $10 \mathrm{~min}$ at room temperature in the dark. Slides were rinsed two times with PBS. Cells were embedded with anti-fade prior to analysis under a Fluorescence Inversion Microscope System (DMI4000B) by using an ultra violet excitation wavelength in the range of $350-370 \mathrm{~nm}$ and detection at $465 \mathrm{~nm}$ (blue). Although both normal cell nucleus and apoptotic bodies were stained as blue, it was easy to identify the apoptotic bodies or apoptotic cell nucleus with highly intensified blue fluorescein.

\section{Terminal Deoxynucleotidyl Transferase-mediated dUTP- biotin Nick End Labeling (TUNEL) Assay of Cell Apoptosis}

In situ Cell Death Detection Kit (Roche Applied Science, Mannheim, Germany) was purchased for detection of apoptosis at single-cell level, based on labeling of DNA strand breaks (TUNEL technology). Analysis was done by fluorescence microscopy. A549 human alveolar epithelial cells were seeded on glass and cultured in six wells with DMEM containing 10\% FBS. Cells were divided into vehicle-treated group, HDX-treated group, HDX + GSH-treated group, and HDX + NAC-treated group. Before drug administration, all cells were starved for $24 \mathrm{~h}$. In HDX + GSH-treated group, $5 \mathrm{mM}$ GSH was administered $30 \mathrm{~min}$ before HDX treatment. In HDX + NAC-treated group, $1 \mathrm{mM} \mathrm{NAC}$ was administered 30 min before HDX treatment. After drug treatment, slides were washed twice with PBS before fixation with $4 \%$ paraformaldehyde in PBS for $1 \mathrm{~h}$ at $15-20^{\circ} \mathrm{C}$. Then, slides were rinsed with $\mathrm{PBS}$ and incubated in permeabilization $(0.1 \%$ Triton X-100 in $0.1 \%$ sodium citrate) for $2 \mathrm{~min}$ on ice. Slides were rinsed twice with PBS before TUNEL reaction mixture was added. TUNEL reaction mixture was prepared by adding
$50 \mu \mathrm{l}$ of enzyme solution to $450 \mu \mathrm{l}$ of label solution. Samples were covered with coverslip during incubation in a humidified chamber for $60 \mathrm{~min}$ at $37^{\circ} \mathrm{C}$ in the dark. Slides were rinsed three times with PBS. Nuclei were subsequently stained with PI for 5 min and rinsed in PBS for two times. Samples were embedded with anti-fade prior to analysis under a confocal laser-scanning microscope (TCS SP5) by use of an excitation wavelength in the range of $450-500 \mathrm{~nm}$ and detection in the range of $515-565 \mathrm{~nm}$ (green) for TUNEL, as well as an excitation wavelength at $535 \mathrm{~nm}$ and emission wavelength at $615 \mathrm{~nm}$ (red) for PI.

\section{Statistical Analysis}

Data are expressed as mean \pm s.d. ANOVA followed by post-hoc analysis (Newman-Keuls test) was used to compare differences among groups. $P<0.05$ was considered statistically significant. SPSS 13.0 (SPSS, Chicago, IL, USA) was used for data analysis.

\section{RESULTS}

\section{OA Induced ALI}

To establish the ALI rat model, OA at $0.1 \mathrm{ml} / \mathrm{kg}$ was intravenously injected into rats, and lung injury variables including gross and microscopic morphology of lung tissue, $\mathrm{H} \& \mathrm{E}$ staining of lung tissue, ratio of W/D lung weight, $\mathrm{PaCO}_{2}, \mathrm{PaO}_{2}$, and $\mathrm{pH}$ levels were determined. Compared with the normal lung architecture, open alveoli and thin alveolar walls in control rats, OA-treated rats showed significantly increased ratio of W/D lung weight $(2 \mathrm{~h}, P<0.01$; 6h, $P<0.05$; Figure 1b), decreased $\mathrm{PaO}_{2}(2 \mathrm{~h}, P<0.01 ; 6 \mathrm{~h}$, $P<0.01$; Figure 1c), increased $\mathrm{PaCO}_{2}(2 \mathrm{~h}, P<0.01 ; 6 \mathrm{~h}$, $P<0.01$; Figure $1 \mathrm{~d})$, and decreased $\mathrm{pH}(2 \mathrm{~h}, P<0.01 ; 6 \mathrm{~h}$, $P<0.01$; Figure 1e), with widespread inflammatory infiltration, thickened alveolar walls and septa, and hemorrhaging and proteinaceous exudate filling some alveoli (Figure 1a). Our observations indicated successful establishment of the ALI rat model.

\section{Downregulation of $\mathrm{SO}_{2} / \mathrm{AAT} 1 / \mathrm{AAT} 2$ Pathway in OA-Treated Rats}

To explore whether the endogenous $\mathrm{SO}_{2}$ levels changed during the development of ALI, we examined the level of $\mathrm{SO}_{2} / \mathrm{AAT} 1 /$ AAT2 in rat lung tissues. Compared with control rats, OA-treated rats showed significantly decreased content of $\mathrm{SO}_{2}(2 \mathrm{~h}, P<0.01 ; 6 \mathrm{~h}, P<0.05$; Figure $2 \mathrm{c})$ and downregulated protein expression of AAT1 $(2 \mathrm{~h}, P<0.01 ; 6 \mathrm{~h}$, $P<0.01)$ and AAT2 in rat lung tissue $(2 \mathrm{~h}, P<0.01 ; 6 \mathrm{~h}$, $P<0.01$; Figure $2 \mathrm{a}$ and $\mathrm{b})$. Therefore, endogenous $\mathrm{SO}_{2} / \mathrm{AAT} 1 / \mathrm{AAT} 2$ pathway was downregulated in OA-treated rats.

\section{$\mathrm{SO}_{2}$ Alleviated OA-Induced ALI}

To understand how $\mathrm{SO}_{2}$ regulated ALI, we upregulated endogenous $\mathrm{SO}_{2}$ levels by administering $\mathrm{SO}_{2}$ derivatives, $\mathrm{Na}_{2} \mathrm{SO}_{3} / \mathrm{NaHSO}_{3}(0.54 \mathrm{mmol} / \mathrm{kg}$, intraperitoneally), to rats 
a

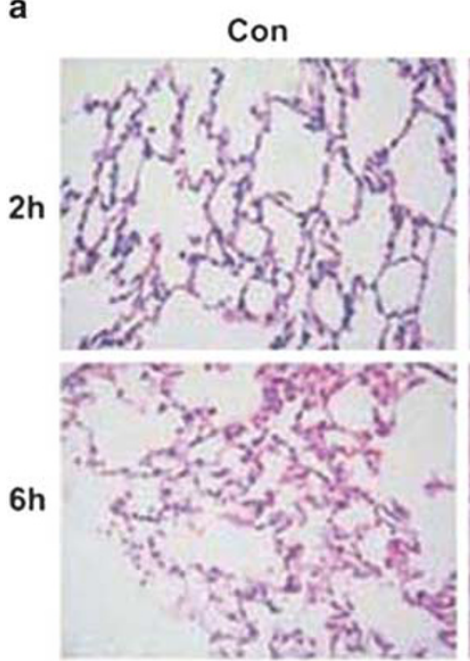

OA

$\mathrm{OA}+\mathrm{SO}_{2}$

$\mathrm{SO}_{2}$
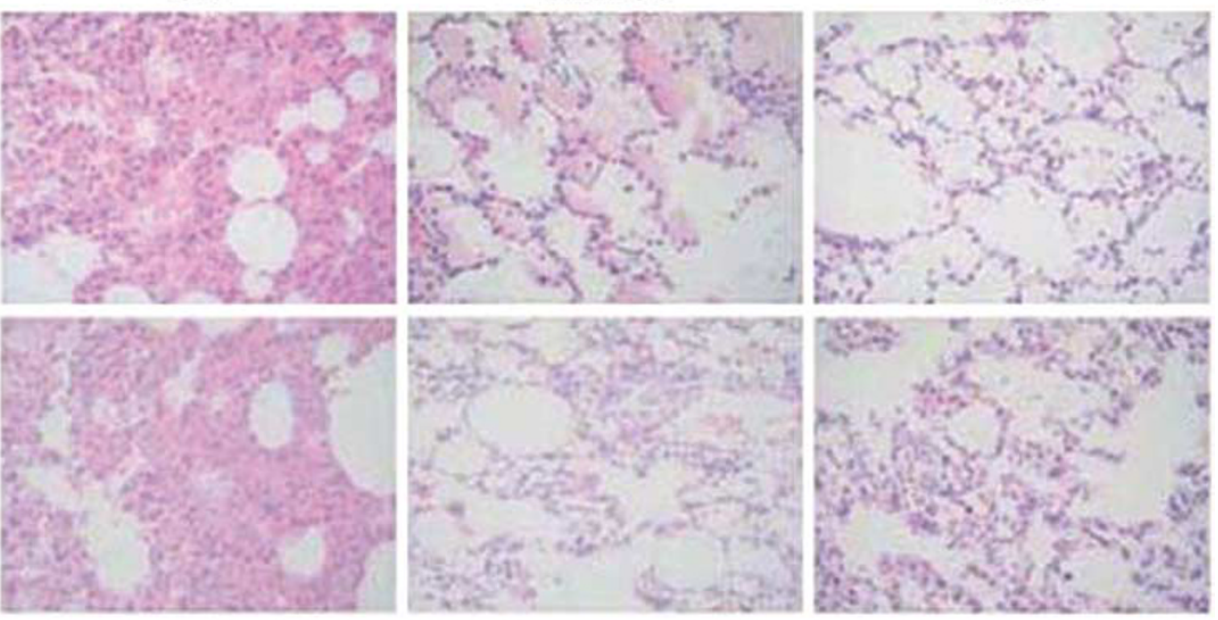

b

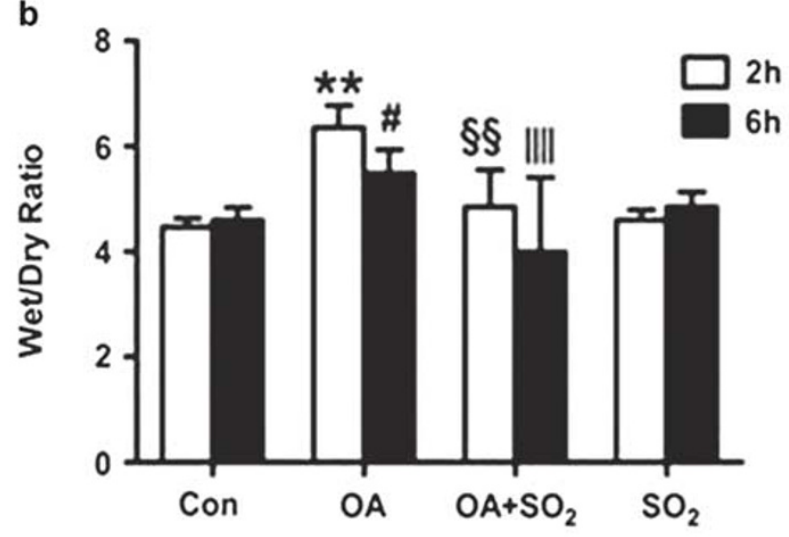

d

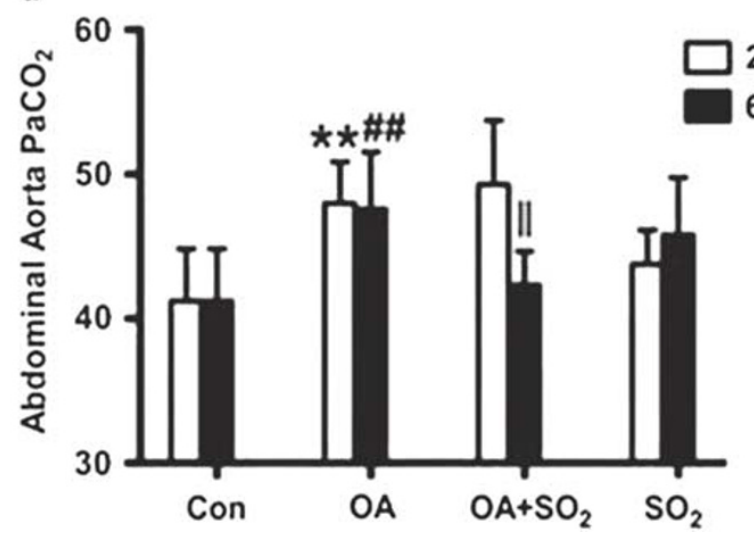

c

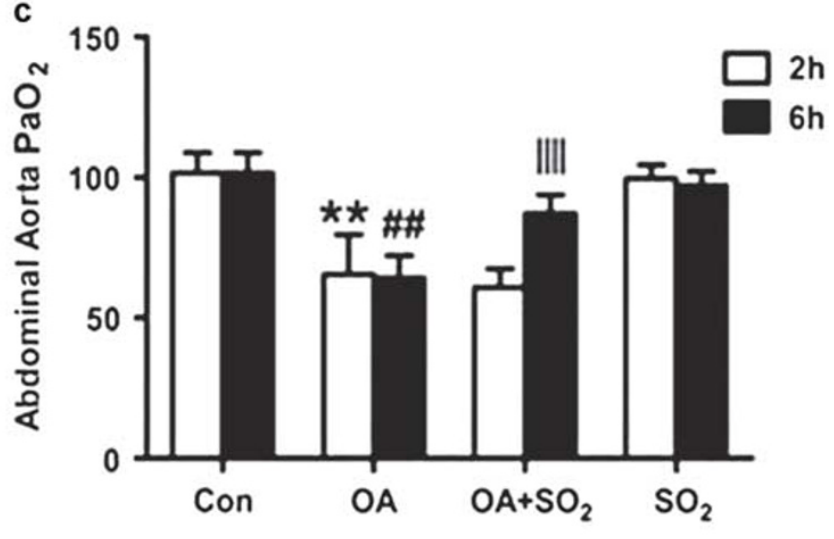

e

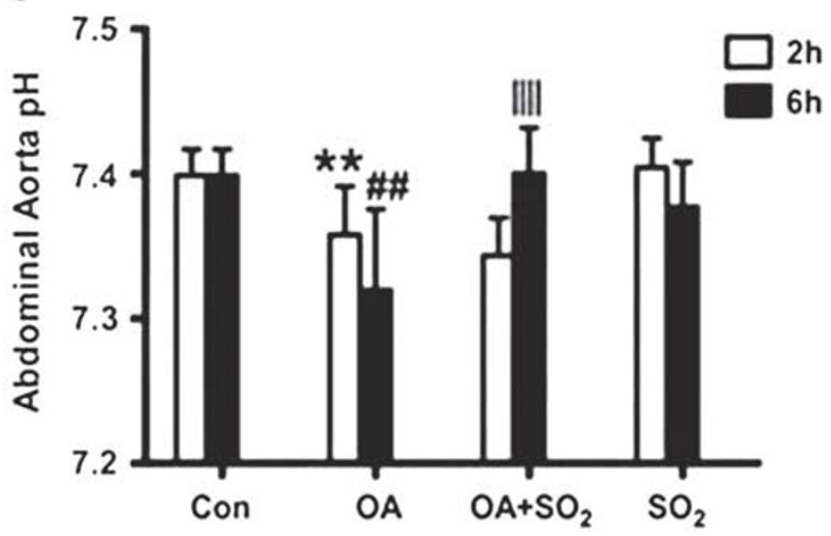

Figure 1 Oleic acid (OA) induced acute lung injury in rats. (a) Representative histological analysis of the lungs from rats treated with OA or sulfur dioxide $\left(\mathrm{SO}_{2}\right)$ for 2 and $6 \mathrm{~h}(400 \times)$. (b) Lung wet/dry ratio. (c) Partial pressure of oxygen $\left(\mathrm{PaO}_{2}\right)$ in abdominal aorta blood. (d) Partial pressure of carbon dioxide $\left(\mathrm{PaCO}_{2}\right)$. (e) $\mathrm{pH}$ levels. Data are represented as mean \pm s.d. $(n=10),{ }^{* *} P<0.01$ vs 2 -h control; ${ }^{\#} P<0.05,{ }^{\# \#} P<0.01$ vs 6 -h control; ${ }^{\S \S} P<0.01$ vs 2 -h OA; ${ }^{\prime \prime} P<0.05$ vs 6-h OA; ${ }^{\prime l l} P<0.01$ vs 6-h OA.

30 min before OA treatment. $\mathrm{SO}_{2}$ content $(2 \mathrm{~h}, P<0.01 ; 6 \mathrm{~h}$, $P<0.05$; Figure 2c) was significantly increased with administration of $\mathrm{SO}_{2}$ donor as compared with $\mathrm{OA}$ alone. Along with the increased endogenous $\mathrm{SO}_{2}$ generation, ratio of W/D lung weight was decreased ( $2 \mathrm{~h}, P<0.01$; $6 \mathrm{~h}, P<0.01$; Figure $1 \mathrm{~b}$ ), $\mathrm{PaO}_{2}$ in arterial blood was increased (6h, $P<0.01$; Figure $\left.1 \mathrm{c}\right)$, $\mathrm{PaCO}_{2}$ was decreased (6h, $\mathrm{P}<0.05$; Figure $\left.1 \mathrm{~d}\right)$, and $\mathrm{pH}$ was increased ( $6 \mathrm{~h}, P<0.01$; Figure 1e), while, development of 

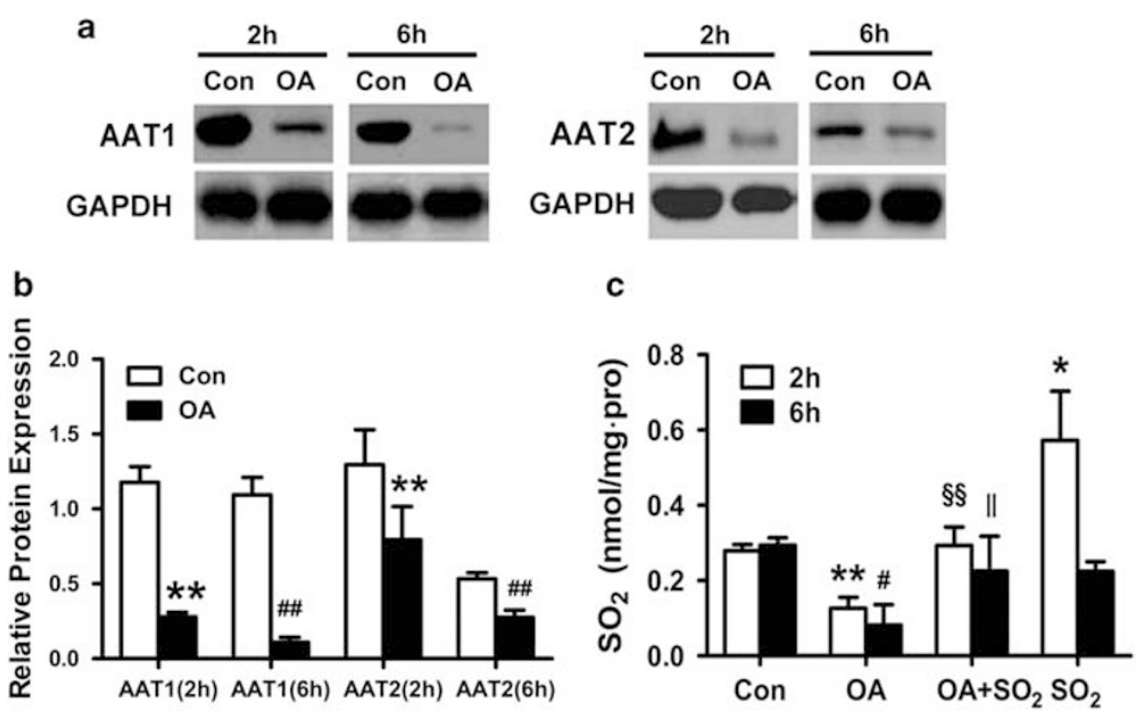

Figure 2 Oleic acid (OA) administration downregulated sulfur dioxide $\left(\mathrm{SO}_{2}\right)$ /aspartate aminotransferase 1 (AAT1)/AAT2 levels in rat lungs. (a) Western blot analysis of AAT1 and AAT2 protein expression in lung tissue after treatment with $\mathrm{OA}$ or $\mathrm{SO}_{2}$ for 2 and $6 \mathrm{~h}$ and (b) quantification. (c) $\mathrm{SO}_{2}$ content in lung tissue after $\mathrm{OA}$ or $\mathrm{SO}_{2}$ administration. Data are represented as mean \pm s.d. $(n=6),{ }^{*} P<0.05,{ }^{*} P<0.01$ vs 2 -h control; ${ }^{*} P<0.05$ vs 6 -h control; ${ }^{\S} P<0.01$ vs 2 -h OA; ${ }^{\prime \prime} P<0.05$, IIII $P<0.01$ vs 6-h OA.

lung injury was attenuated, with reduced infiltration, maintenance of alveolar wall thickness, and absence of hemorrhaging and proteinaceous exudate induced by OA as compared with OA-treated rats (Figure 1a). Hence, reversal of OA-induced decreased endogenous $\mathrm{SO}_{2}$ levels alleviated ALI.

\section{$\mathrm{SO}_{2}$ Alleviated OA-Induced Oxidative Stress in Rat Lung Tissue}

$\mathrm{SO}_{2}$ reduced oxygen radical generation

Administration of OA significantly elevated levels of $\mathrm{OH}^{-}$ $(2 \mathrm{~h}, P<0.05 ; 6 \mathrm{~h}, P<0.05$; Figure $3 \mathrm{a})$ and $\mathrm{H}_{2} \mathrm{O}_{2}(2 \mathrm{~h}$, $P<0.05 ; 6 \mathrm{~h}, P<0.01$; Figure $3 \mathrm{~b}$ ), but $\mathrm{SO}_{2}$ administration profoundly reversed the elevated levels of $\mathrm{OH}^{-}(2 \mathrm{~h}$, $P<0.05$; 6h, $P<0.05$; Figure 3a) and $\mathrm{H}_{2} \mathrm{O}_{2}(6 \mathrm{~h}, P<0.01$; Figure $3 \mathrm{~b})$.

\section{$\mathrm{SO}_{2}$ inhibited lipid peroxidation}

MDA generation was significantly augmented $(2 \mathrm{~h}, P<0.05$; $6 \mathrm{~h}, P<0.01$; Figure 3c) in OA-treated rat lung tissue, but $\mathrm{SO}_{2}$ significantly attenuated the MDA levels $(2 \mathrm{~h}, P<0.05 ; 6 \mathrm{~h}$, $P<0.05$; Figure $3 \mathrm{c}$ ), with no difference in MPO generation (Figure 3d).

Antioxidant capacity was augmented with $\mathrm{SO}_{2}$ administration Compared with control rats, OA-treated rats showed markedly decreased TAC $(2 \mathrm{~h}, P<0.01 ; 6 \mathrm{~h}, P<0.01$; Figure $3 \mathrm{e})$ and levels of catalase ( $2 \mathrm{~h}, P<0.01 ; 6 \mathrm{~h}, P<0.05$; Figure 3f), SOD $(2 \mathrm{~h}, P<0.01 ; 6 \mathrm{~h}, P<0.01$; Figure $3 \mathrm{~g})$, and GPx $(6 \mathrm{~h}$, $P<0.01$; Figure $3 \mathrm{~h})$. However, $\mathrm{SO}_{2}$ administration significantly increased TAC $(2 \mathrm{~h}, P<0.05 ; 6 \mathrm{~h}, P<0.05$; Figure $3 \mathrm{e})$ and levels of catalase $(6 \mathrm{~h}, P<0.05$; Figure $3 \mathrm{f})$, SOD
$(2 \mathrm{~h}, P<0.05 ; 6 \mathrm{~h}, P<0.05$; Figure $3 \mathrm{~g})$, and GPx $(6 \mathrm{~h}$, $P<0.01$ ) in OA-treated rats (Figure $3 \mathrm{~h}$ ).

$\mathrm{SO}_{2}$ could regulate GSH/GSSG generation in OA-treated rat lung tissue

In OA-treated rat lung tissue, generation of GSH $(2 \mathrm{~h}, P<0.01$; $6 \mathrm{~h}, P<0.01$; Figure 3i) was decreased, but with increased generation of GSSG ( $2 \mathrm{~h}, P<0.05 ; 6 \mathrm{~h}, P<0.01$; Figure 3j), which was reversed by $\mathrm{SO}_{2}$ administration (Figure $3 \mathrm{i}$ and $\mathrm{j}$ ).

$\mathrm{SO}_{2}$ reduced NO/iNOS level in OA-treated rat lung tissue Administration of $\mathrm{OA}$ significantly increased levels of $\mathrm{NO}$ $(2 \mathrm{~h}, P<0.01 ; 6 \mathrm{~h}, P<0.01$; Figure $3 \mathrm{k})$ and iNOS $(2 \mathrm{~h}, P<0.01)$ in rats (Figure 31), but $\mathrm{SO}_{2}$ reduced the elevated levels of NO $(2 \mathrm{~h}, P<0.05 ; 6 \mathrm{~h}, P<0.01$; Figure $3 \mathrm{k})$ and iNOS $(2 \mathrm{~h}$, $P<0.05$; Figure 31).

$\mathrm{SO}_{2}$ upregulated $\mathrm{SOD1/SOD2}$ expression in rat lung tissue We detected SOD1 and SOD2 protein expression in rat lung tissues. Compared with control rats, OA-treated rats showed decreased levels of SOD1 $(2 \mathrm{~h}, \quad P<0.01)$ and SOD2 ( $2 \mathrm{~h}, P<0.05 ; 6 \mathrm{~h}, P<0.01$; Figure $4 \mathrm{~b}$ and $\mathrm{d}$ ), which could be reversed $(2 \mathrm{~h}, P<0.01 ; 6 \mathrm{~h}, P<0.01)$ with $\mathrm{SO}_{2}$ treatment (Figure $4 \mathrm{~b}$ and $\mathrm{d}$ ). In addition, we detected SOD1 and SOD2 expression in rat lung tissue by semi-quantitative immunohistochemistry. Compared with control rats, OA-treated rats showed downregulated expression of SOD1 $(2 \mathrm{~h}, P<0.01)$ and SOD2 ( $2 \mathrm{~h}, P<0.01 ; 6 \mathrm{~h}, P<0.01$; Figure $4 \mathrm{a}$ and $\mathrm{c})$ in lung tissue, but administration of $\mathrm{SO}_{2}$ significantly reversed the downregulated expression of SOD1 $(2 \mathrm{~h}, P<0.01)$ and SOD2 ( $2 \mathrm{~h}, P<0.01$; $6 \mathrm{~h}, P<0.01$; Figure $4 \mathrm{a}$ and c) as compared with $\mathrm{OA}$ rats. 


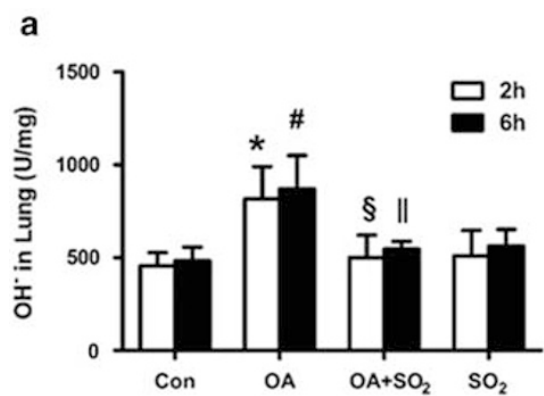

b

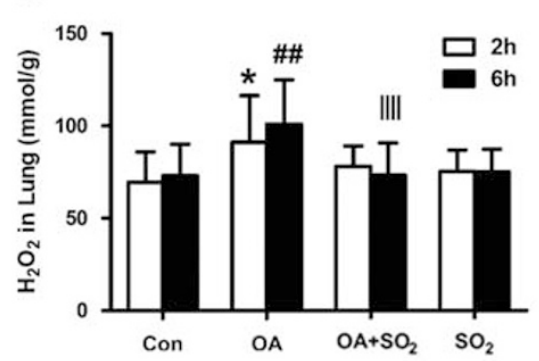

e

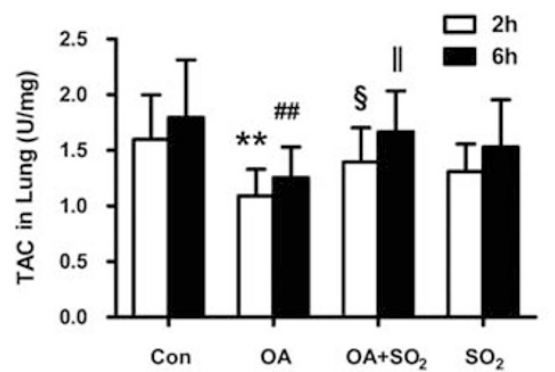

h

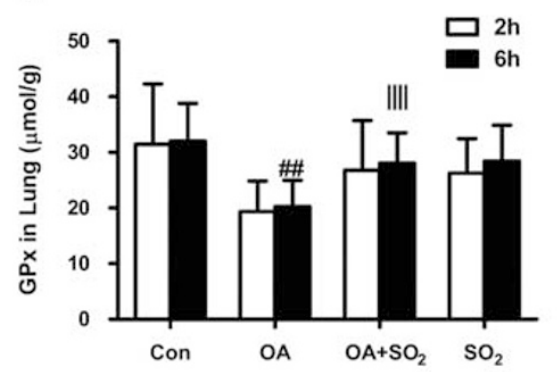

k

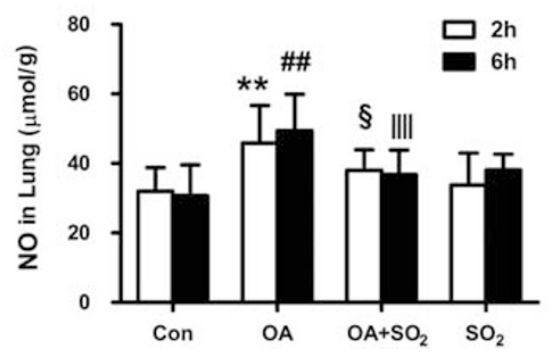

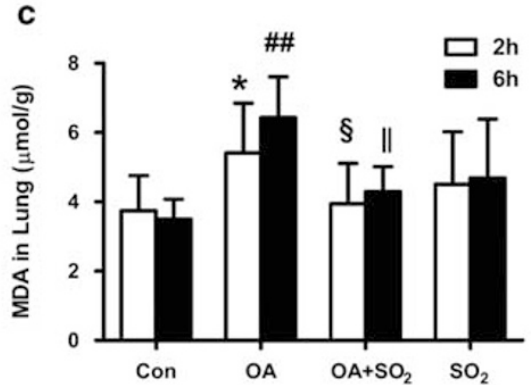

f

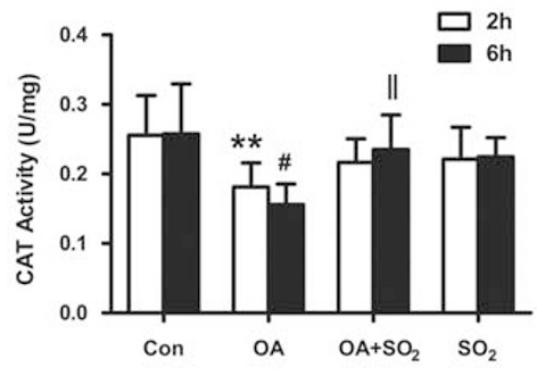

i

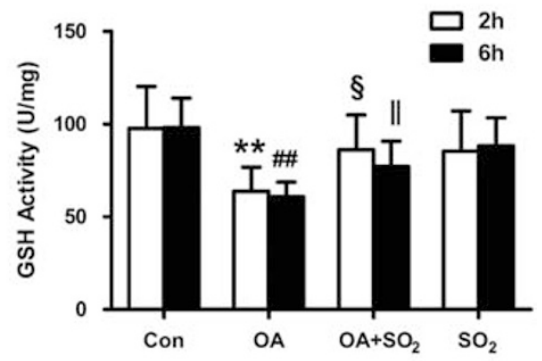

I

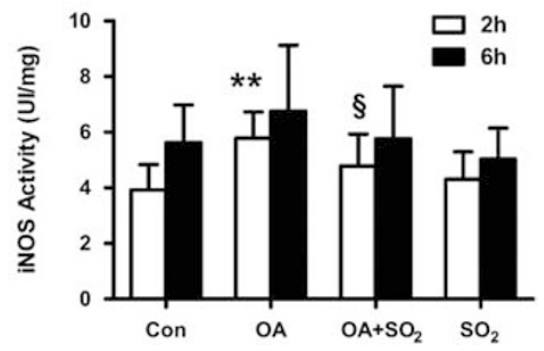

Figure $3 \mathrm{SO}_{2}$ alleviated oleic acid (OA)-induced oxidative stress in rat lung tissue. (a, b) Hydroxyl radical $\left(\mathrm{OH}^{-}\right)$and hydrogen peroxide $\left(\mathrm{H}_{2} \mathrm{O}_{2}\right)$ production in lung tissue treated with $\mathrm{OA}$ or $\mathrm{SO}_{2}$. (c, d) Malondialdehyde (MDA) generation and myeloperoxidase (MPO) activity in rat lungs. (e, g) Total antioxidant capacity (TAC), catalase (CAT) and superoxide dismutase (SOD) activity in rat lungs. (h) Glutathione peroxidase (GPx), (i, $\mathbf{j})$ glutathione (GSH) activity and glutathion disulfide (GSSG) production in rat lungs. (k, I) Nitric oxide (NO) production, and inducible nitric oxide synthase (iNOS) activity in rat lungs. Data are represented as mean \pm s.d. $(n=8),{ }^{*} P<0.05,{ }^{* *} P<0.01$ vs 2 -h control; ${ }^{\#} P<0.05,{ }^{\# \#} P<0.01$ vs 6 -h control; ${ }^{\S} P<0.05$,

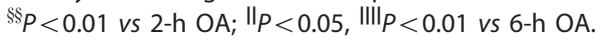

$\mathrm{SO}_{2}$ Decreased $\mathrm{O}_{2}{ }^{-}$and $\mathrm{OH}^{-}$Generation in A549 Cells Treated with $O A$

To further examine whether the downregulated endogenous $\mathrm{SO}_{2}$ pathway participated in the pathogenesis of ALI by promoting oxidative stress, we investigated in vitro the impact of the downregulated endogenous $\mathrm{SO}_{2}$ pathway on
ROS, including $\mathrm{O}_{2}{ }^{-}$and $\mathrm{OH}^{-}$. A549 human alveolar epithelial cells treated with $10-100 \mu \mathrm{M}$ OA and $50 \mu \mathrm{M}$ $\mathrm{SO}_{2}$ exhibited no significant cytotoxicity as compared with vehicle-treated cells (Figure 5a). Similar to our in vivo findings, A549 cells incubated with OA $(10 \mu \mathrm{M})$ for 30 min showed a significantly downregulated AAT1 protein 
a
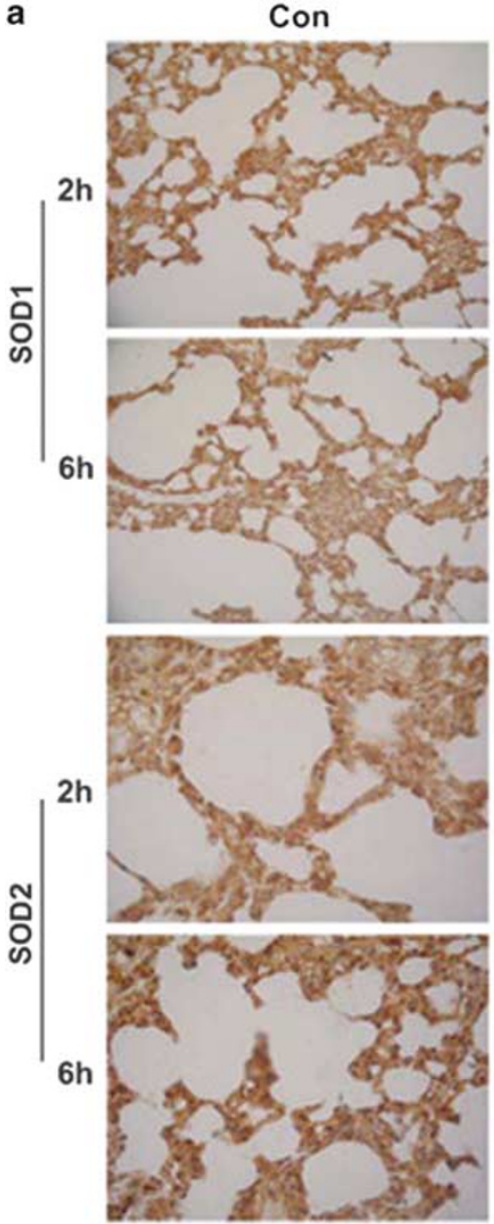

OA
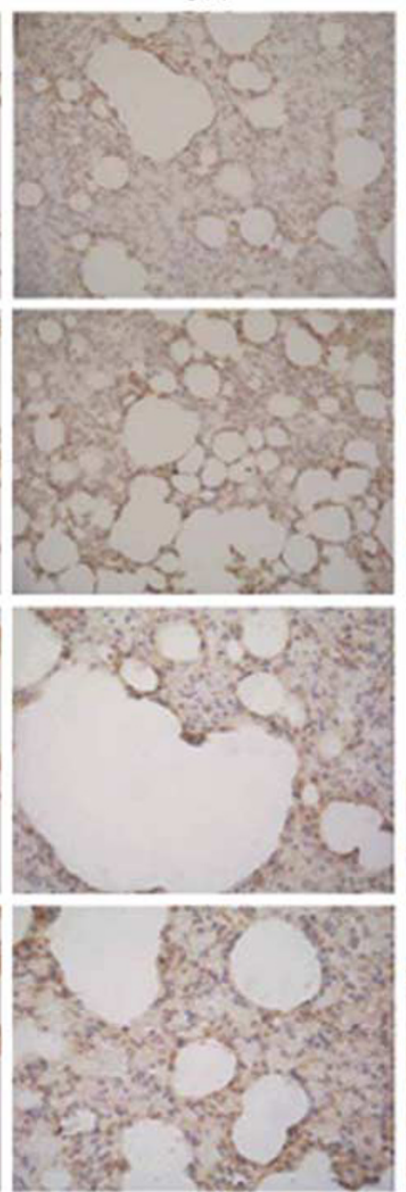

$\mathrm{OA}+\mathrm{SO}_{2}$
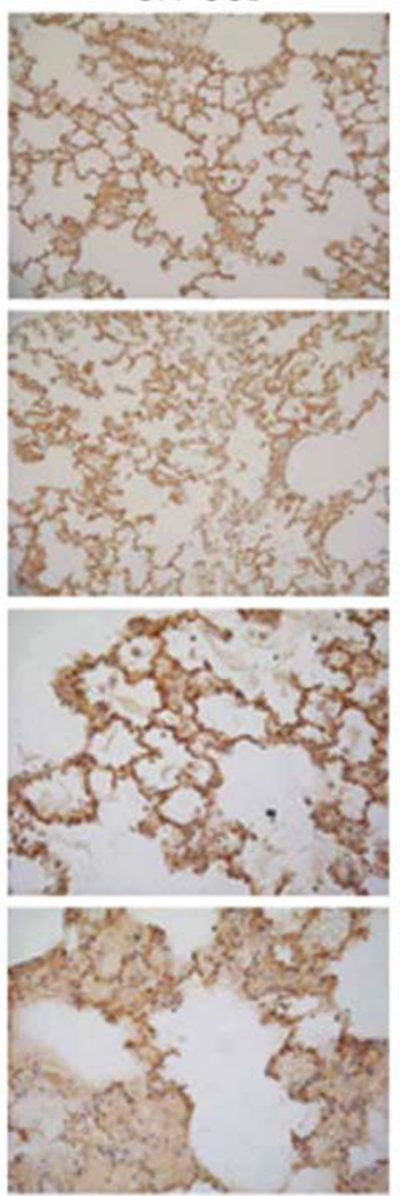

$\mathrm{SO}_{2}$
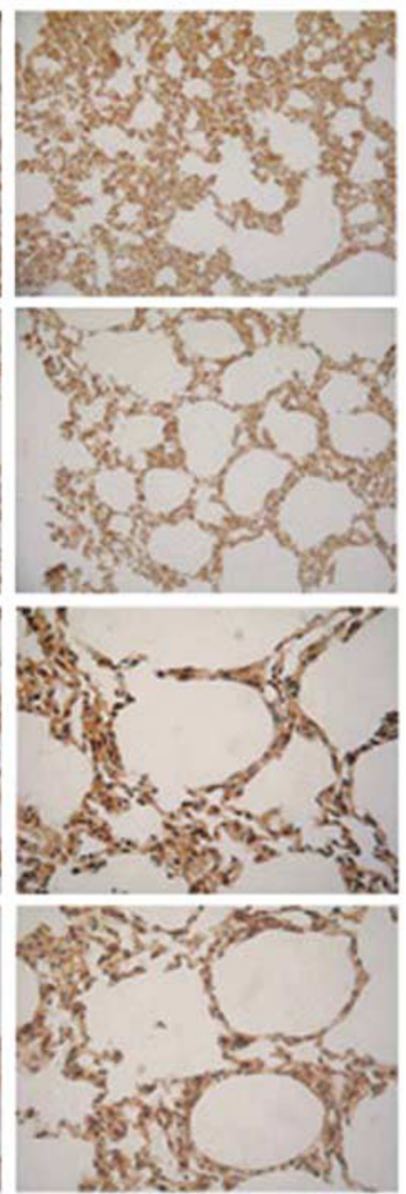

b
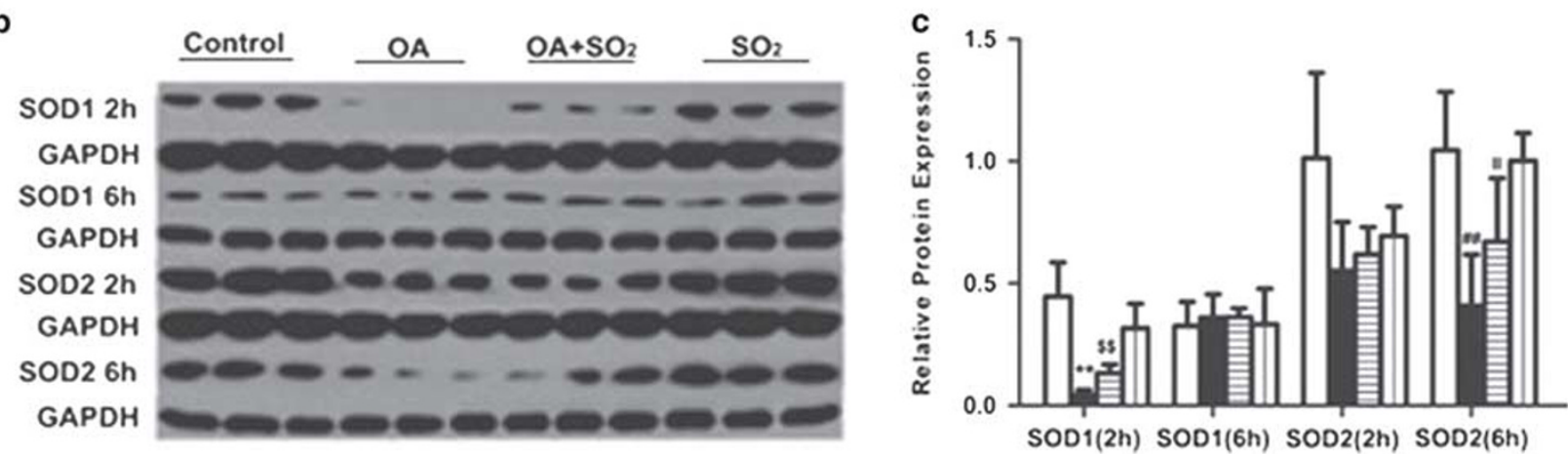

Figure 4 Sulfur dioxide $\left(\mathrm{SO}_{2}\right)$ upregulated superoxide dismutase 1 (SOD1)/SOD2 expression in rat lung tissue. (a) Immunohistochemistry of SOD1 and SOD2 expression with oleic acid (OA) or $\mathrm{SO}_{2}$ treatment (SOD1, $200 \times$; SOD2, $400 \times$ ). (b) Western blot analysis of SOD1 and SOD2 protein expression and (c) quantification of western blot analysis. Data are represented as mean \pm s.d. $(n=8),{ }^{*} P<0.05,{ }^{* *} P<0.01$ vs $2 \mathrm{~h}$ control; ${ }^{\# \#} P<0.01$ vs 6 -h control; ${ }_{\$} P_{P}<0.01$ vs 2 -h OA; $I I I I P<0.01$ vs 6-h OA.

expression $(P<0.01$; Figure $5 b)$ with significantly elevated generation of $\mathrm{O}_{2}^{-}$(Figure $\left.5 \mathrm{c}\right)$ and $\mathrm{OH}^{-} \quad(P<0.01$; Figure 5d) as compared with vehicle-treated cells. However, treatment with the $\mathrm{SO}_{2}$ donor $(50 \mu \mathrm{M})$ for 30 min before $\mathrm{OA}$ administration significantly downregulated $\mathrm{O}_{2}{ }^{-}$and $\mathrm{OH}^{-}(P<0.01)$ generation as compared with $\mathrm{OA}$ treatment alone (Figure $5 \mathrm{c}$ and $\mathrm{d}$ ). Therefore, OA-induced downregulation of endogenous $\mathrm{SO}_{2}$ generation contributed to free radical insult, and recovery of the OA-induced downregulated endogenous $\mathrm{SO}_{2}$ levels inhibited ROS generation, which confirmed that downregulation of the endogenous $\mathrm{SO}_{2}$ pathway contributed to the development of ALI by promoting oxidative stress in lung tissue and alveolar cells. 
a

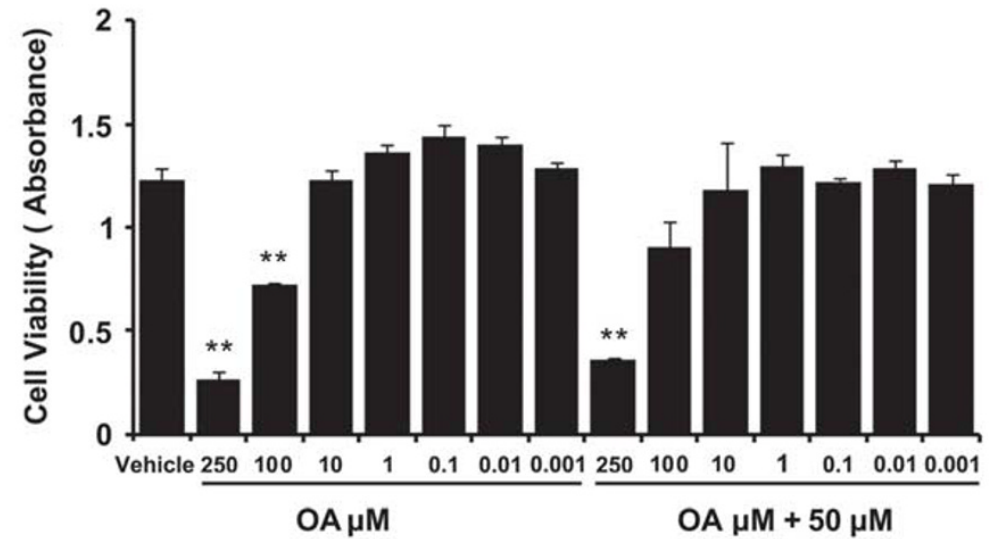

C

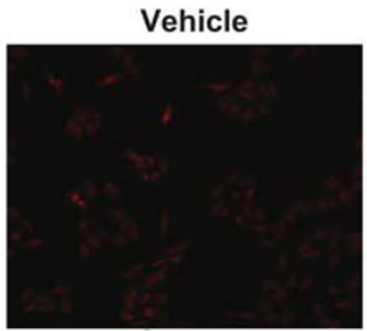

OA

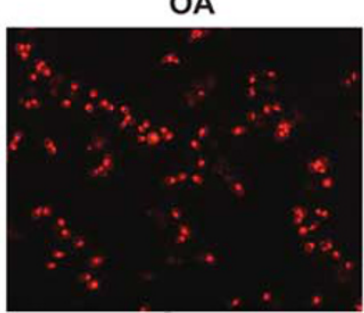

$\mathrm{OA}+\mathrm{SO}_{2}$

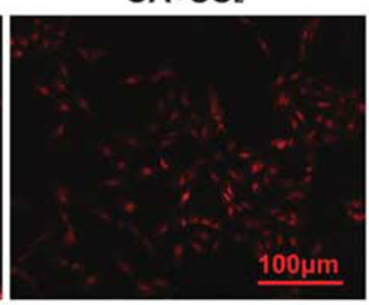

b
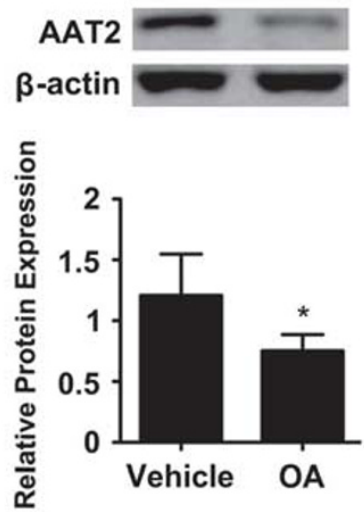

d

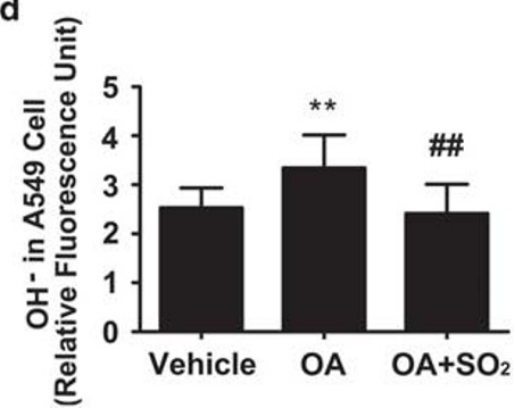

Figure 5 Sulfur dioxide $\left(\mathrm{SO}_{2}\right)$ decreased $\mathrm{O}_{2}{ }^{-}$and hydroxyl radical $\left(\mathrm{OH}^{-}\right)$generation in human alveolar epithelial A549 cells treated with oleic acid (OA). (a) A549 cell viability assay after treatment with different concentrations of OA or $\mathrm{SO}_{2}$. (b) AAT2 protein expression in A549 cells treated with OA or $\mathrm{SO}_{2}$. (c) Superoxide anion $\left(\mathrm{O}_{2}{ }^{-}\right.$) generation in A549 cells detected by dihydroethidium (DHE) fluorescence probe. (d) Quantification of hydroxyl radical $\left(\mathrm{OH}^{-}\right)$generation in A549 cells by fluorescence analysis. Data are represented as mean \pm s.d. $(n=9),{ }^{*} P<0.05,{ }^{* *} P<0.01$ vs vehicle; ${ }^{\sharp} P<0.05$, $\# P<0.01$ vs $\mathrm{OA}$.

$\mathrm{HDX}$, an Inhibitor of $\mathrm{SO}_{2}$ Production, Upregulated $\mathrm{O}_{2}$ Generation and Promoted Apoptosis in A549 Cells

To further verify the mechanism by which downregulated $\mathrm{SO}_{2}$ participates in the pathogenesis of ALI via promoting oxidative stress, we examined the impact of downregulated $\mathrm{SO}_{2}$ production on alveolar epithelial cell free radical generation and cell injury in vitro. $\operatorname{HDX}(150 \mu \mathrm{M})$, an inhibitor of $\mathrm{SO}_{2}$ generating enzymes, when incubated with A549 cells for $1 \mathrm{~h}$ markedly reduced $\mathrm{SO}_{2}$ generation (Supplementary Figure S2A and B), decreased AAT activities (Supplementary Figure S2C and D), as well as elevated $\mathrm{O}_{2}{ }^{-}$generation as compared with vehicle treatment. However, in the presence of GSH $(5 \mathrm{mM})$ or NAC $(1 \mathrm{mM})$, potent radical scavengers, $30 \mathrm{~min}$ before HDX treatment the elevated $\mathrm{O}_{2}{ }^{-}$generation was significantly abolished (Figure 6a). To evaluate if the cell injury was caused by oxidative stress, we examined the change in PARP, caspase-3 activation, as well as the degree of apoptosis. Compared with vehicle treatment, HDX treatment significantly upregulated PARP expression (Figure 6b), increased the ratio of cleaved caspase- 3 to caspase-3 $(P<0.01$; Figure $6 \mathrm{c})$, as well as promoted cell apoptosis (Figure 7), which was reversed by GSH $(P<0.05)$ or NAC $(P<0.05)$. Thus, downregulated endogenous $\mathrm{SO}_{2}$ production contributed to free radical insult, resulting in alveolar epithelial cell PARP and caspase-3 activation, and promoted cell apoptosis, thus confirming that the downregulated endogenous $\mathrm{SO}_{2}$ pathway was involved in the development of cell injury by augmenting oxygen radical generation.

\section{DISCUSSION}

Alveolar cells are crucial to maintain alveolar fluid homeostasis, and when disrupted, they may contribute to ALI/ ARDS, a life-threatening condition with high incidence in the United States and an overall mortality that is comparable to the number of deaths attributed to breast cancer. ${ }^{27}$ The molecular mechanism responsible for lung injury has attracted abundant studies, and the crucial role of oxidative stress in the pathogenesis of lung disease has been wellestablished. Through the elicitation of oxidative stress, engineered nanoparticles (NP) might contribute to proinflammatory disease processes in the lung. ${ }^{28}$ Oxidative stress and ROS such as $\mathrm{O}_{2}{ }^{-}$and $\mathrm{OH}^{-}$play a prominent role in the alcoholic lung. ${ }^{29}$ In normobaric hyperoxia, the production of peroxynitrite by the reaction of $\mathrm{NO}$ with $\mathrm{O}_{2}{ }^{-}$, caused pulmonary oxidative damage that might ultimately 
a

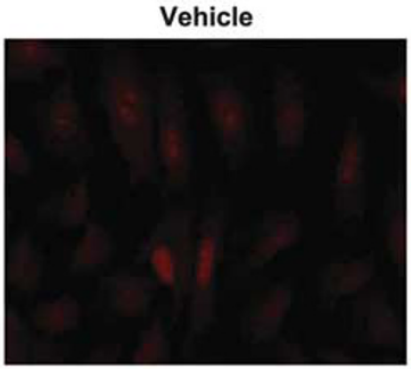

b
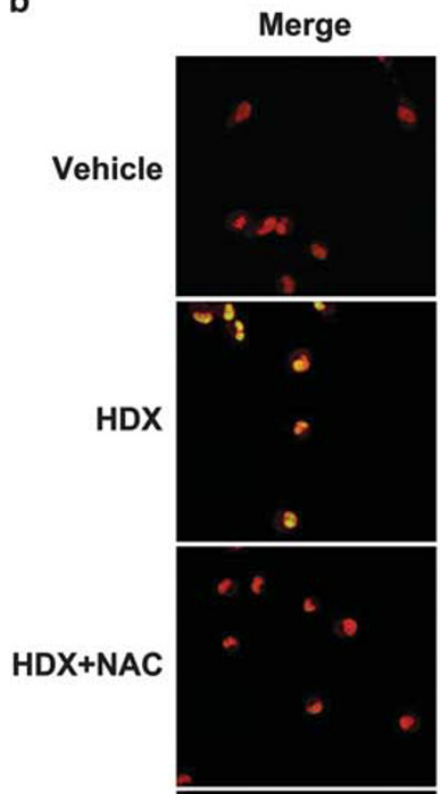

HDX+GSH

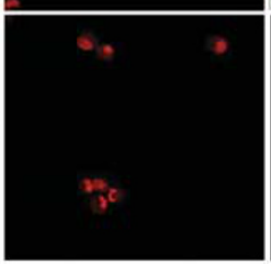

HDX

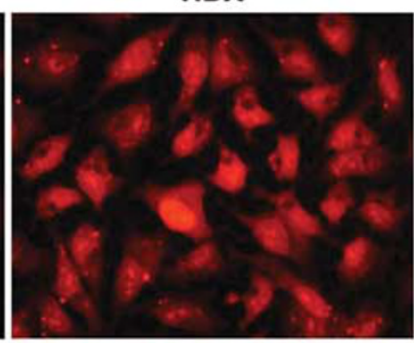

PARP
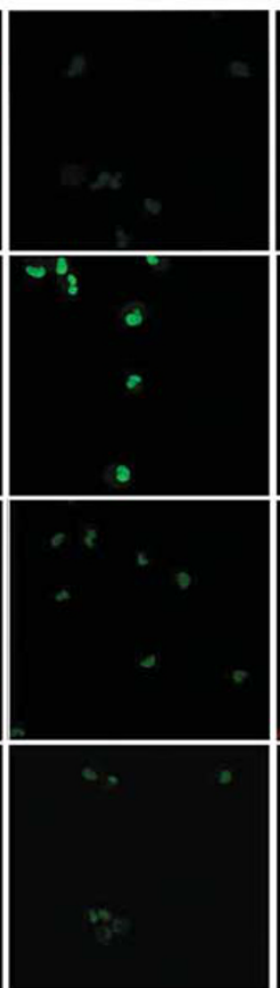

PI
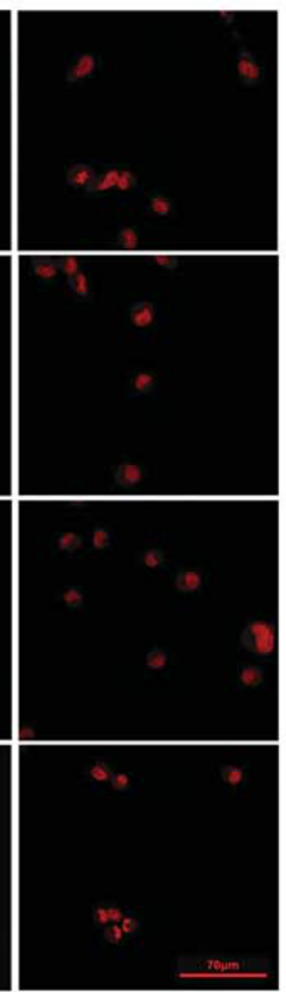

HDX+NAC

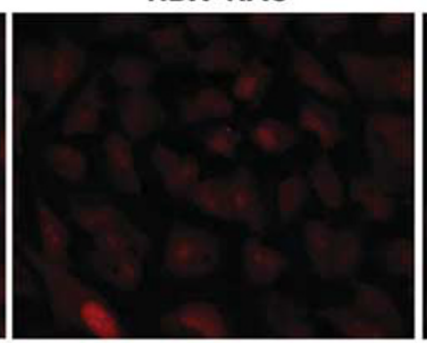

C
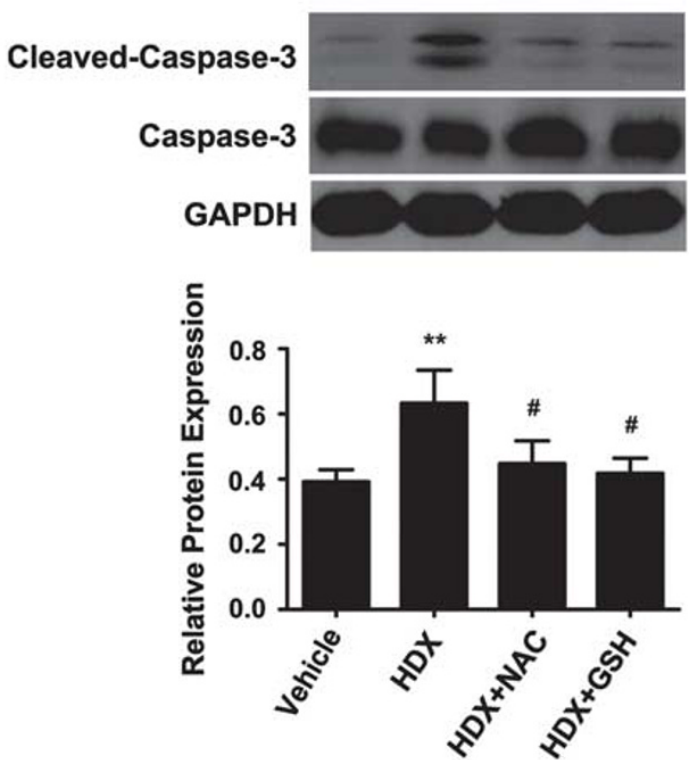

Figure $6 \mathrm{~L}$-aspartic acid- $\beta$-hydroxamate ( $\mathrm{HDX}$; inhibitor of $\mathrm{SO}_{2}$ production) upregulated $\mathrm{O}_{2}{ }^{-}$generation, poly (ADP-ribose) polymerase (PARP) expression, as well as cleaved caspase-3 protein expression in $\mathrm{A} 549$ cells. (a) DHE fluorescence probe detection of superoxide anion $\left(\mathrm{O}_{2}{ }^{-}\right) \mathrm{generation}$ in A549 cells treated with HDX for $1 \mathrm{~h}$, gluathione (GSH) or N-acetyl-L-cysteine (NAC) for $1.5 \mathrm{~h}$. (b) Confocal laser-scanning microscopy of PARP localization in A549 cells. (c) Protein expression of cleaved caspase-3 and caspase-3, and quantification of their ratio in A549 cells treated with HDX, GSH, or NAC. Data are represented as mean \pm s.d. $(n=9)$, ${ }^{*} P<0.01$ vs vehicle; ${ }^{\#} P<0.05$ vs HDX.

contribute to fatal pulmonary edema. ${ }^{30}$ ROS and RNS play important roles in regulating cell survival, and a sudden excessive and prolonged surge of ROS/RNS could induce cell death. ${ }^{31}$ In most tissues, the first line of defense against oxidative stress is the endogenous antioxidant defense system such as SODs: SOD1 in the cytoplasm, SOD2 in mitochondria, and SOD3 in the extracellular space. ${ }^{32}$ Furthermore, free radical insult might activate PARP and culminate in an apoptotic cascade. ${ }^{33}$ Caspase- 3 is a potent, terminal caspase that executes apoptosis. ${ }^{34,35}$ Despite advances in the pathogenesis of oxidative stress in ALI, the underlying molecular mechanism remains poorly clarified.
Recent studies have suggested that $\mathrm{SO}_{2}$ is a novel endogenous gaseous signaling molecule involved in the regulation of cardiovascular function. ${ }^{14}$ Endogenous $\mathrm{SO}_{2}$ protects against isoproterenol-induced myocardial injury and increases myocardial antioxidant capacity in rats, $^{18}$ and might play a protective role in the pathogenesis of monocrotalin-induced pulmonary hypertension and promote endogenous antioxidative capacities, ${ }^{36}$ suggesting that endogenous $\mathrm{SO}_{2}$ was involved in the regulation of cardiovascular oxidative stress. ${ }^{37}$ Regardless of recent research on the emerging protective role of endogenous $\mathrm{SO}_{2}$ in maintaining homeostasis in vivo, little has been revealed 
regarding the role of endogenous $\mathrm{SO}_{2}$ in the pathogenesis of ALI/ARDS.

To examine the role of the endogenous $\mathrm{SO}_{2}$ /AAT1/AAT2 pathway in the development of ALI, we established a rat model of OA-induced ALI and determined the level of endogenous $\mathrm{SO}_{2}$ /AAT1/AAT2 pathway. Rats administered with OA showed severe lung injury. Compared with control rats, OA-treated rats showed profoundly decreased $\mathrm{SO}_{2}$ content, as well as downregulated AAT1 and AAT2 protein expression. In addition, AAT2 protein expression in OA-treated A549 human alveolar epithelial cells was also downregulated as compared with vehicle-treated cells. These results suggested that $\mathrm{OA}$ downregulated the endogenous $\mathrm{SO}_{2} / \mathrm{AAT} 1 / \mathrm{AAT} 2$ pathway and induced ALI.

To understand the role of downregulated $\mathrm{SO}_{2}$ /AAT1/AAT2 pathway in the development of OA-induced ALI, we supplemented $\mathrm{SO}_{2}$ donor to increase $\mathrm{SO}_{2}$ concentration to see if sufficient $\mathrm{SO}_{2}$ levels could prevent the development of OA-induced ALI. The results showed that compared with $\mathrm{OA}$-treated rats, $\mathrm{OA}+\mathrm{SO}_{2}$ donor rats showed an increased $\mathrm{SO}_{2}$ content in lung tissue and an alleviated ALI, suggesting that possibly the pathogenesis of OA-induced ALI at least partially involved downregulation of endogenous $\mathrm{SO}_{2}$ production.

Then, we tested the mechanisms by which $\mathrm{SO}_{2}$ protects against ALI. Extensive literatures have boasted the essential role of oxidative stress in the development of OA-induced ALI. ${ }^{38-41}$ Intravenous administration of OA could produce neutrophil activation as well as endothelium damage, resulting in abundant ROS generation and decreased activity or protein expression of SOD and catalase probably through downregulation of NADPH oxidase-dependent pathway or upregulation of NF- $\kappa \mathrm{B}$ phosphorylation at p $65 .{ }^{42-45}$ Thus, we designed in vitro and in vivo experiments to investigate the possible impact of $\mathrm{SO}_{2}$ pathway on lung tissue oxidative stress.

First, we downregulated endogenous $\mathrm{SO}_{2}$ generation by treating A549 human alveolar epithelial cells with OA or $\mathrm{HDX}$, an inhibitor of endogenous $\mathrm{SO}_{2}$ synthesis enzyme.
HDX could function as a competitive inhibitor of L-glutamate uptake from astrocytes, ${ }^{46}$ and inhibit excitatory amino acid-stimulated phosphoinositide hydrolysis in rat hippocampus. ${ }^{47,48}$ Moreover, HDX could inhibit matrix metalloproteinases and AAT activities, in addition to reversing the increased AAT levels in plasma as demonstrated by a few rat experiments. ${ }^{49-51}$ Furthermore, HDX could inhibit AAT activities and the generation of endogenous $\mathrm{SO}_{2}$ in both pulmonary tissues and myocardium. ${ }^{17,18,36}$ The present results showed that compared with vehicle-treated cells, $\mathrm{OA}$ induced a marked reduction of $\mathrm{SO}_{2}$ generation but a significant increase in $\mathrm{O}_{2}{ }^{-}$and $\mathrm{OH}^{-}$generation, which could be reversed by supplementation of $\mathrm{SO}_{2}$. HDX-treated cells generated significantly increased oxygen radicals and markedly upregulated caspase-3 cleavage and PARP expression, resulting in cell injury and apoptosis demonstrated by TUNEL and Hoechst staining. In contrast, in the presence of GSH or NAC (both strong radical eliminators), HDX failed to promote alveolar epithelial cell radical generation, PARP upregulation, caspase-3 activation or apoptosis, suggesting that the downregulated $\mathrm{SO}_{2}$ pathway markedly facilitated the oxidative stress and thus likely induced apoptosis.

Then, an in vivo experiment was designed to investigate the effect of $\mathrm{SO}_{2}$ on oxidative stress in OA-treated ALI rats, and the findings were inconsistent with in vitro observations. OA-treated rats demonstrated a markedly downregulated endogenous $\mathrm{SO}_{2}$ generation in rat lungs as well as a significant augmentation of oxidative stress and ALI reflected by profoundly increased production of $\mathrm{OH}^{-}, \mathrm{H}_{2} \mathrm{O}_{2}, \mathrm{MDA}$, and GSSG and decreased levels of antioxidants such as SOD1, SOD2, GSH, and catalase in rat lungs, in addition to overt pulmonary damage exhibited by increased $\mathrm{PaCO}_{2}$, decreased $\mathrm{PaO}_{2}$, decreased $\mathrm{pH}$, widespread inflammatory infiltration, thickened alveolar walls, hemorrhage, and proteinaceous exudate filling alveoli. While increasing the downregulated $\mathrm{SO}_{2}$ level by supplementation with $\mathrm{SO}_{2}$ increased the activity of SOD1, SOD2, and catalase, improved TAC, reduced oxygen radical generation, alleviated ALI, suggesting that sufficient endogenous $\mathrm{SO}_{2}$ generation assists in maintaining
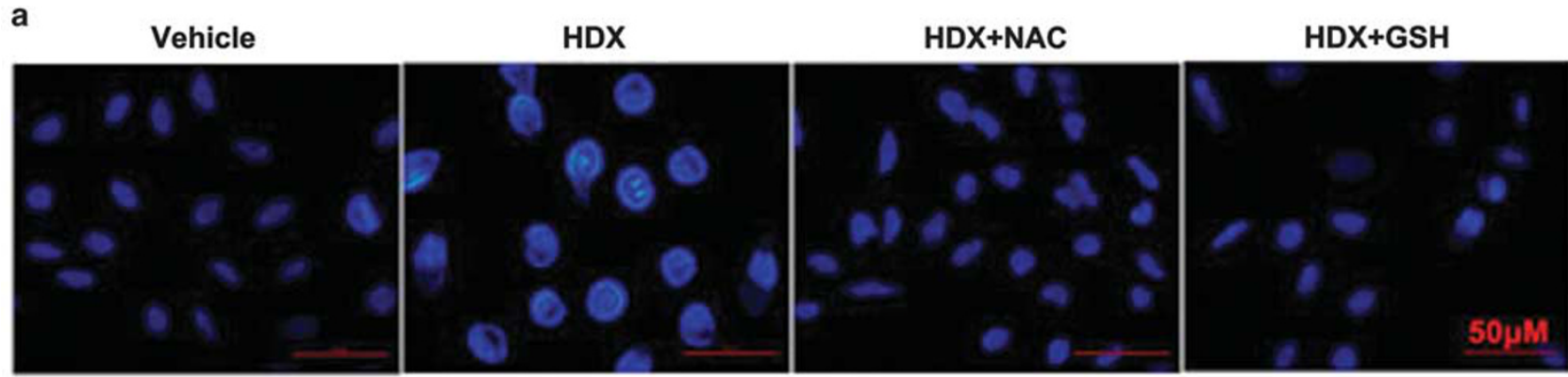

Figure 7 L-aspartic acid- $\beta$-hydroxamate (HDX; inhibitor of $\mathrm{SO}_{2}$ production) promoted apoptosis in $\mathrm{A} 549$ cells. (a) Hoechst staining of apoptotic cell nucleus and apoptotic bodies in A549 cells treated with HDX for $1 \mathrm{~h}$, gluathione (GSH) or N-acetyl-L-cysteine (NAC) for $1.5 \mathrm{~h}$. (b) Terminal deoxynucleotidyl transferase-mediated dUTP-biotin nick end labeling (TUNEL) assay of cell apoptosis in A549 cells treated with HDX, GSH, or NAC. 
b

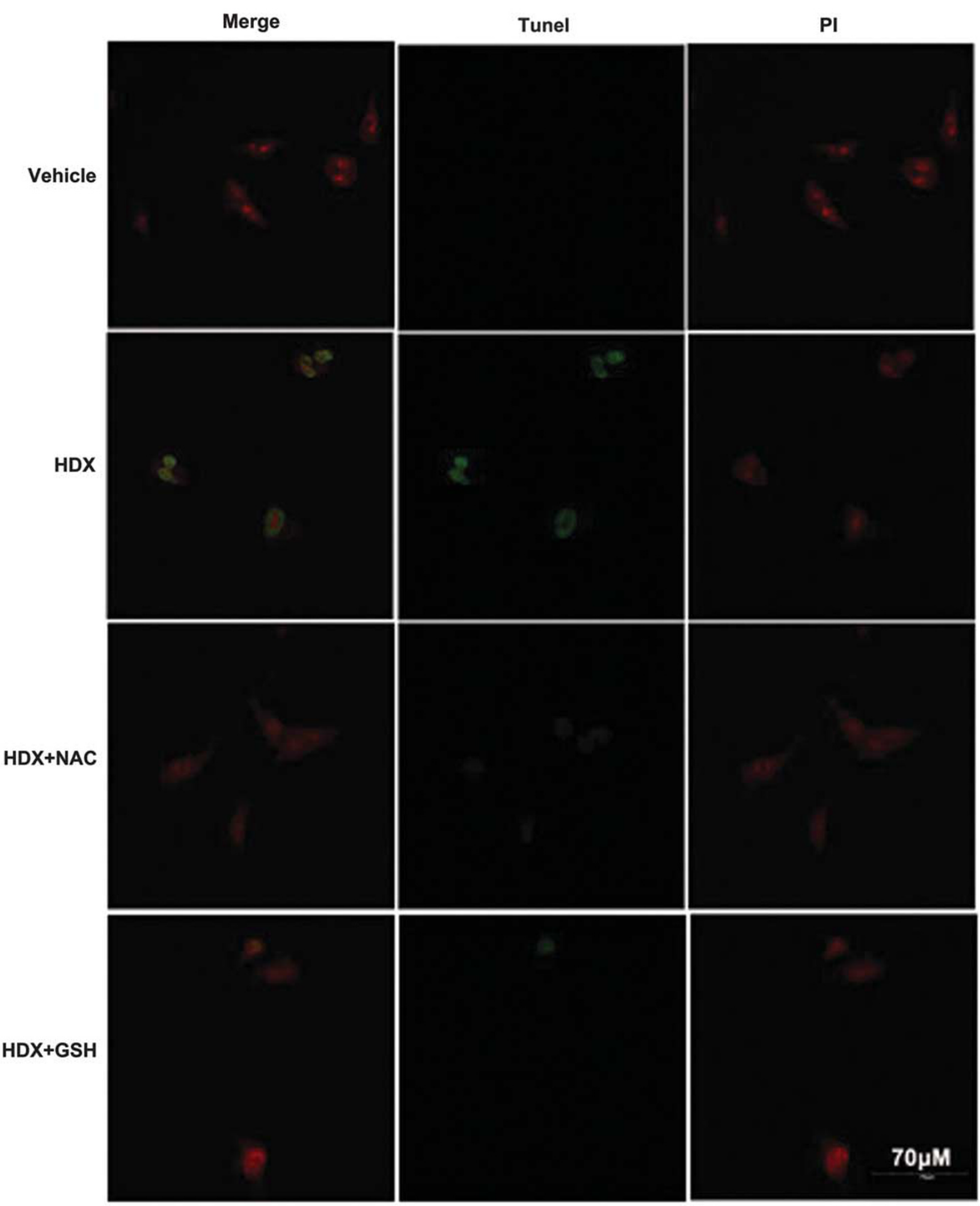

Figure 7 Continued.

oxidant and antioxidant balance, whereas upsetting endogenous $\mathrm{SO}_{2}$ pathway might contribute to oxidative stress, resulting in cell injury and apoptosis. The exact mechanisms responsible for inhibition of $\mathrm{SOD}$ and catalase by $\mathrm{SO}_{2}$ is not fully clear. Liang et $a l^{18}$ reported that $\mathrm{SO}_{2}$ increased antioxidant capacity in rats with myocardial injury. Our 
previous study suggested that $\mathrm{SO}_{2}$ might upregulate $\mathrm{H}_{2} \mathrm{~S} / \mathrm{CSE}$ and $\mathrm{H}_{2} \mathrm{~S}$ /MPST pathways in pulmonary arteries of hypoxic rats, resulting a decrease of oxidative stress. ${ }^{52}$ And $\mathrm{SO}_{2}$ preconditioning could significantly reduce I/R-induced myocardial injury in vivo in association with increased myocardial antioxidative capacity, upregulated myocardial $\mathrm{H}_{2} \mathrm{~S} / \mathrm{CSE}$ pathway but downregulated NO/iNOS pathway. ${ }^{53}$ It has been unclear if $\mathrm{SO}_{2}$ has any chemical modifications on $\mathrm{SOD}$ or not. Up to now, the study suggested that $\mathrm{SO}_{2}$ inhibited the oxidative stress likely via the increase of antioxidative capacity of the cells. It was found that $\mathrm{SO}_{2}$ decreased cardiomyocyte apoptosis likely via stimulation of mitochondrial potential. ${ }^{54}$ Clarifying detailed mechanisms by which $\mathrm{SO}_{2}$ impacts the oxidative stress and apoptosis needs further studies.

Oxygen therapy is a classical option for the treatment of ALI. ${ }^{1}$ Steroids are sometimes used in the treatment of ALI for its major effect of anti-inflammation, improving the lung injury. ${ }^{55}$ However, the use of steroids is clinically controversial due to its side effects, eg, infection, etc. In our study, we discovered that $\mathrm{SO}_{2}$ could inhibit the oxidative stressinduced lung injury, resulting in the improvement of gas exchange and thus increase $\mathrm{PaO}_{2}$ in ALI animals. Therefore, $\mathrm{SO}_{2}$ has potential significance of helping with increasing $\mathrm{O}_{2}$ tension together with oxygen therapy in the treatment of ALI. However, the potential mechanisms for the effect of $\mathrm{SO}_{2}$ are still in need of further investigation.

Hence, we concluded that downregulated endogenous $\mathrm{SO}_{2} / \mathrm{AAT} 1 / \mathrm{AAT} 2$ pathway is involved in the development of $\mathrm{OA}$-induced ALI. $\mathrm{SO}_{2}$ could protect against the development of OA-induced ALI by inhibiting oxidative stress. The results of the present study may extend our understanding of the pathogenesis of ALI and provide evidence for the emerging regulatory role of endogenous $\mathrm{SO}_{2}$ in maintaining homeostasis of the respiratory system.

Supplementary Information accompanies the paper on the Laboratory Investigation website (http://www.laboratoryinvestigation.org)

\section{ACKNOWLEDGMENTS}

We thank Dingfang Bu and Yaqian Huang for their technical assistance. This work was supported by the National Natural Science Foundation of China (31130030), the Major Basic Research Development Program of People's Republic of China (2012CB517806, 2011CB503904), and the National Natural Science Foundation of China (91439110, 31440052).

\section{DISCLOSURE/CONFLICT OF INTEREST}

The authors declare no conflict of interest.

1. Luh SP, Chiang $\mathrm{CH}$. Acute lung injury/acute respiratory distress syndrome (ALI/ARDS): the mechanism, present strategies and future perspectives of therapies. J Zhejiang Univ Sci B 2007;8:60-69.

2. Reiss $L K$, Uhlig U, Uhlig S. Models and mechanisms of acute lung injury caused by direct insults. Eur J Cell Biol 2012;91:590-601.

3. Tejera P, Wang Z, Zhai R, et al. Genetic polymorphisms of peptidase inhibitor 3 (elafin) are associated with acute respiratory distress syndrome. Am J Respir Cell Mol Biol 2009;41:696-704.
4. Howden R, Cho HY, Miller-DeGraff L, et al. Cardiac physiologic and genetic predictors of hyperoxia-induced acute lung injury in mice. Am J Respir Cell Mol Biol 2012;46:470-478.

5. Zmijewski JW, Lorne E, Zhao X, et al. Antiinflammatory effects of hydrogen peroxide in neutrophil activation and acute lung injury. Am J Respir Crit Care Med 2009;179:694-704.

6. Safdar Z, Yiming M, Grunig G, et al. Inhibition of acid-induced lung injury by hyperosmolar sucrose in rats. Am J Respir Crit Care Med 2005;172:1002-1007.

7. Jain $D$, Atochina-Vasserman EN, Tomer $Y$, et al. Surfactant protein $D$ protects against acute hyperoxic lung injury. Am J Respir Crit Care Med 2008;178:805-813.

8. Imai Y, Kuba K, Neely GG, et al. Identification of oxidative stress and Toll-like receptor 4 signaling as a key pathway of acute lung injury. Cell 2008;133:235-249.

9. Tasaka S, Amaya F, Hashimoto $S$, et al. Roles of oxidants and redox signaling in the pathogenesis of acute respiratory distress syndrome. Antioxid Redox Signal 2008;10:739-753.

10. Carnesecchi S, Pache JC, Barazzone-Argiroffo C. NOX enzymes: potential target for the treatment of acute lung injury. Cell Mol Life Sci 2012;69:2373-2385.

11. Lee IT, Yang CM. Role of NADPH oxidase/ROS in pro-inflammatory mediators-induced airway and pulmonary diseases. Biochem Pharmacol 2012;84:581-590.

12. Marriott HM, Jackson LE, Wilkinson TS, et al. Reactive oxygen species regulate neutrophil recruitment and survival in pneumococcal pneumonia. Am J Respir Crit Care Med 2008;177:887-895.

13. Velayutham M, Hemann C, Zweier JL. Removal of $\mathrm{H}(2) \mathrm{O}(2)$ and generation of superoxide radical: role of cytochrome $\mathrm{c}$ and $\mathrm{NADH}$. Free Radic Biol Med 2011;51:160-170.

14. Chen SS, Tang CS, Jin HF, et al. Sulfur dioxide acts as a novel endogenous gaseous signaling molecule in the cardiovascular system. Chi Med J (Engl) 2011;12:1901-1905.

15. Luo LM, Chen S, Jin HF, et al. Endogenous generation of sulfur dioxide in rat tissues. Biochem Biophys Res Commun 2011;415:61-67.

16. Wang XB, Jin HF, Tang CS, et al. The biological effect of endogenous sulfur dioxide in the cardiovascular system. Eur J Pharmacol 2011; 670:1-6.

17. Sun $Y$, Tian $Y$, Prabha $M$, et al. Effects of sulfur dioxide on hypoxic pulmonary vascular structural remodeling. Lab Invest 2010;90:68-82.

18. Liang $Y$, Liu $D$, Ochs $T$, et al. Endogenous sulfur dioxide protects against isoproterenol-induced myocardial injury and increases myocardial antioxidant capacity in rats. Lab Invest 2011;91:12-23.

19. Türkoğlu S, Muz MH, Ozercan R, et al. Effects of lycopene on the model of oleic acid-induced acute lung injury. Tuberk Toraks 2012;60: 101-107.

20. Ishitsuka $Y$, Moriuchi $H$, Isohama $Y$, et al. A selective thromboxane A2 (TXA2) synthase inhibitor, ozagrel, attenuates lung injury and decreases monocyte chemoattractant protein-1 and interleukin-8 mRNA expression in oleic acid-induced lung injury in guinea pigs. J Pharmacol Sci 2009;111:211-215.

21. Lai JP, Bao S, Davis IC, et al. Inhibition of the phosphatase PTEN protects mice against oleic acid-induced acute lung injury. $\mathrm{Br} J$ Pharmacol 2009;156:189-200.

22. Wang $X B$, Huang $X M$, Ochs $T$, et al. Effect of sulfur dioxide preconditioning on rat myocardial ischemia/reperfusion injury by inducing endoplasmic reticulum stress. Basic Res Cardiol 2011;106: 865-878.

23. Usui $S$, Oveson BC, Iwase $T$, et al. Overexpression of SOD in retina: need for increase in $\mathrm{H} 2 \mathrm{O} 2$-detoxifying enzyme in same cellular compartment. Free Radic Biol Med 2011;51:1347-1354.

24. Jin HF, Cong B, Zhao B, et al. Effects of hydrogen sulfide on hypoxic pulmonary vascular structural remodeling. Life Sci 2006;78:1299-1309.

25. Li Y. Nuclear Factor-kappa B is activated by hyperoxia but does not protect from cell death. J Biol Chem 1997;272:20646-20649.

26. Li Z, Shi K, Guan L, et al. ROS leads to MnSOD upregulation through ERK2 translocation and p53 activation in selenite-induced apoptosis of NB4 cells. FEBS Lett 2010;584:2291-2297.

27. Rubenfeld GD, Caldwell E, Peabody E, et al. Incidence and outcomes of acute lung injury. N Engl J Med 2005;353:1685-1693.

28. Li N, Xia T, Nel AE. The role of oxidative stress in ambient particulate matter-induced lung diseases and its implications in the toxicity of engineered nanoparticles. Free Radic Biol Med 2008;44:1689-1699. 
29. Johnson LN, MKoval M. Cross-talk between pulmonary injury, oxidant stress, and gap junctional communication. Antioxid Redox Signal 2009;11:355-367.

30. Carlsson LM, Jonsson J, Edlund T, et al. Mice lacking extracellular superoxide dismutase are more sensitive to hyperoxia. Med Sci 1995;92:6264-6268.

31. Biswas SK, Rahman I. Environmental toxicity, redox signaling and lung inflammation: the role of glutathione. Mol Aspects Med 2009;30:60-76.

32. Reddi AR, Jensen LT, Naranuntarat A, et al. The overlapping roles of manganese and $\mathrm{Cu} / \mathrm{Zn}$ SOD in oxidative stress protection. Free Radic Biol Med 2009;46:154-162.

33. Banasik $M$, Stedeford $T$, Strosznajder RP. Natural inhibitors of poly(ADP-ribose) polymerase-1. Mol Neurobiol 2012;46:55-63.

34. Weaver AN, Yang ES. Beyond DNA repair: additional functions of PARP-1 in cancer. Front Oncol 2013;3:290.

35. Boland $\mathrm{K}$, Flanagan $\mathrm{L}$, Prehn JH. Paracrine control of tissue regeneration and cell proliferation by Caspase-3. Cell Death Dis 2013;4:e725.

36. Jin HF, Du SX, Zhao X, et al. Effects of endogenous sulfur dioxide on monocrotaline-induced pulmonary hypertension in rats. Acta Pharmacol Sin 2008;29:1157-1166.

37. Zhu M, Du J, Liu A, et al. Effect of endogenous sulfur dioxide in regulating cardiovascular oxidative stress. Histol Histopathol 2014;29: 1107-1111.

38. Yang $\mathrm{C}$, Moriuchi $\mathrm{H}$, Takase $\mathrm{J}$, et al. Oxidative stress in early stage of acute lung injury induced with oleic in guinea pigs. Biol Pharm Bull 2003;26:424-428.

39. Metnitz PG, Bartens C, Fischer M, et al. Antioxidant status in patients with acute respiratory distress syndrome. Intensive Care Med 1999;20:180.

40. Chabot F, Mitchell JA, Gutteridge JM, et al. Reactive oxygen species in acute lung injury. Eur Respir J 1998;11:745-757.

41. MacNee W. Oxidants/antioxidants and chronic obstructive pulmonary disease: pathogenesis to therapy. Novartis Found Symp 2001;234:169-185.

42. Liu H, Zhang D, Zhao B, et al. Superoxide anion, the main species of ROS in the development of ARDS induced by oleic acid. Free Radic Res 2004;38:1281-1287.

43. Zhang $H$, Slutsky AS, Vincent JL. Oxygen free radicals in ARDS, septic shock and organ dysfunction. Intensive Care Med 2000;26:474-476.
44. Rahman Q, Abidi P, Afaq F, et al. Glutathione redox system in oxidative lung injury. Crit Rev Toxicol 1999;29:543-568.

45. Scott RB, Reddy KS, Husain K, et al. Dose response of ethanol on antioxidant defense system of liver, lung, and kidney in rat. Pathophysiology 2000;7:25-32.

46. Drejer J, Larsson OM, Schousboe A. Characterization of L-glutamate uptake into and release from astrocytes and neurons cultured from different brain regions. Exp Brain Res 1982;47:259-269.

47. Ormandy GC. Inhibition of excitatory amino acid-stimulated phosphoinositide hydrolysis in rat hippocampus by L-aspartate-betahydroxamate. Brain Res 1992;572:103-107.

48. Littman L, Munir M, Flagg SD, et al. Multiple mechanisms for inhibition of excitatory amino acid receptors coupled to phosphoinositide hydrolysis. J Neurochem 1992;59:1893-1904.

49. Maitra SR, Bhaduri S, Valane PD, et al. Inhibition of matrix metalloproteinases by chemically modified tetracyclines in sepsis. Shock 2003;20:280-285.

50. Maitra SR, Sikha Bhaduri D, El-Maghrabi R, et al. Inhibition of matrix metalloproteinase on hepatic transforming growth factor $\beta 1$ and caspase-3 activation in hemorrhage. Acad Emerg Med 2005;12: 797-803.

51. Maitra SR, Shapiro MJ, Bhaduri S, et al. Effect of chemically modified tetracycline on transforming growth factor- $\beta$ and caspase- 3 activation in liver of septic rats. Crit Care Med 2005;33:1577-1581.

52. Chen SY, Jin HF, Sun Y, et al. Impact of sulfur dioxide on hydrogen sulfide/cystathionine- $\gamma$-lyase and hydrogen sulfide/mercaptopyruvate sulfurtransferase pathways in the pathogenesis of hypoxic pulmonary hypertension in rats. Zhonghua Er Ke Za Zhi 2011;49:890-894.

53. Jin Hf, Wang $\mathrm{Y}, \mathrm{Xb}$ Wang, et al. Sulfur dioxide preconditioning increases antioxidative capacity in rat with myocardial ischemia reperfusion (I/R) injury. Nitric Oxide 2013;32:56-61.

54. Jin H, Liu AD, Holmberg $L$, et al. The role of sulfur dioxide in the regulation of mitochondrion-related cardiomyocyte apoptosis in rats with isopropylarterenol-induced myocardial injury. Int J Mol Sci 2013;14:10465-10482.

55. Araz O, Demirci E, Yilmazel Ucar E, et al. Comparison of reducing effect on lung injury of dexamethasone and bosentan in acute lung injury: an experimental study. Multidiscip Respir Med 2013;8:74. 